\title{
EARTHQUAKE SOURCE IDENTIFICATION AND CHARACTERISATION FOR THE CANTERBURY REGION, SOUTH ISLAND, NEW ZEALAND
}

\author{
Jarg R. Pettinga ${ }^{1}$, Mark D. Yetton ${ }^{1,2}$, Russ J. Van Dissen ${ }^{3}$ and \\ Gaye Downes ${ }^{3}$
}

\begin{abstract}
The Canterbury region of the South Island of New Zealand straddles a wide zone of active earth deformation associated with the oblique continent-continent collision between the Australian and Pacific tectonic plates east of the Alpine fault. The associated ongoing crustal strain is documented by the shallow earthquake activity (at depths of $<40 \mathrm{~km}$ ) and surface deformation expressed by active faulting, folding and ongoing geodetic strain. The level of earth deformation activity (and consequent earthquake hazard) decreases from the northwest to the southeast across the region. Deeper-level subduction related earthquake events are confined to the northernmost parts of the region, beneath Marlborough.

To describe the geological setting and seismological activity in the region we have sub-divided the Canterbury region into eight domains that are defined on the basis of structural styles of deformation. These eight domains provide an appropriate geological and seismological context on which seismic hazard assessment can be based. A further, ninth source domain is defined to include the Alpine fault, but lies outside the region.
\end{abstract}

\begin{abstract}
About 90 major active earthquake source faults within and surrounding the Canterbury region are characterised in terms of their type (sense of slip), geometry (fault dimensions and attitude) and activity (slip rates, single event displacements, recurrence intervals, and timing of last rupture). In the more active, northern part of the region strike-slip and oblique strike-slip faults predominate, and recurrence intervals range from 81 to $>5,000$ years. In the central and southern parts of the region oblique-reverse and reverse/thrust faults predominate, and recurrence intervals typically range from $\sim 2,500$ to $>20,000$ years.

In this study we also review information on significant historical earthquakes that have impacted on the region (e.g. Christchurch earthquakes 1869 and 1870; North Canterbury 1888; Cheviot 1902; Motunau 1922; Buller 1929; Arthurs Pass 1929 and 1994; and others), and the record of instrumental seismicity. In addition, data from available paleoseismic studies within the region are included; and we also evaluate large potential earthquake sources outside the Canterbury region that are likely to produce significant shaking within the region. The most important of these is the Alpine fault, which we include as a separate source domain in this study.
\end{abstract}

The integrated geological and seismological data base presented in this paper provide the foundation for the probabilistic seismic hazard assessment for the Canterbury region, and this is presented in a following companion paper in this Bulletin (Stirling et al. this volume).

\section{INTRODUCTION}

In 1997 Environment Canterbury (then Canterbury Regional Council) instigated an Earthquake Hazard and Risk Assessment Study comprising a five stage, multi-year programme. This programme is outlined in more detail in the preceding companion paper in this issue of the Bulletin (Kingsbury et al. this volume). The aim of Stage 1 (Part A) is to identify and characterise the active geological structures (faults and folds), and compile data on the significant historical earthquakes, instrumental seismicity and paleoseismicity in the Canterbury region (Pettinga et al. 1998). In this paper we present the key results from this Stage 1 (Part A) component of the study. Specifically our objectives are to:

- Summarize the tectonic setting of the Canterbury region with respect to earthquake sources

\footnotetext{
${ }^{1}$ Natural Hazards Research Centre, Department of Geological Sciences

University of Canterbury, Christchurch, (Member)

${ }^{2}$ Geotech Consulting Ltd RD 1 Lyttelton, Christchurch, (Member)

${ }^{3}$ Institute of Geological and Nuclear Sciences, Lower Hutt, (Member)
} 
- Locate and characterise all known active faults and folds in the Canterbury region

- Compile and tabulate all relevant available information on these identified earthquake sources within the region

- Review information on historical earthquake activity, instrumental seismicity, and available paleoseismic studies within the region

- Identify and characterise potential large earthquake sources outside the Canterbury region which are likely to produce significant shaking within the region, and

- Provide the basis for a comprehensive Probabilistic Seismic Hazard Assessment (PSHA) for the Canterbury region.

The Canterbury region is geographically extensive, and the documented widespread active earth deformation is complex, and directly related to its location straddling the wider Australia-Pacific plate boundary zone. The identification and characterisation (including available paleoseismic data) of the many major earthquake sources, combined with the spatial and temporal distribution of seismicity, including the historic occurrence of large earthquakes, is a crucial first step toward developing a regional approach to probabilistic seismic hazard assessment (PSHA). The following Stage 1 (Part B) of Environment Canterbury's Earthquake Hazard and Risk Assessment Study, is a detailed probabilistic hazard assessment for the region (Stirling et al. 1999), and a summary of this study is presented in the following companion paper in this issue of the bulletin (Stirling et al. this volume).

\section{THE STUDY AREA}

The study area includes the entire Environment Canterbury's local authority region. We also have included areas immediately surrounding the Canterbury region, as major earthquakes there may also impact in Canterbury. The boundary of the Canterbury region, and the location of the main urban areas are shown in Figure 1 of the preceding companion paper (Kingsbury et al., this volume). The main urban areas include Christchurch, Timaru, Ashburton, Kaikoura, Rangiora, and Kaiapoi.

\section{BACKGROUND TO EARTHQUAKE SOURCE CHARACTERISATION AND STUDY METHODOLOGY}

Traditionally, regional earthquake hazard studies have primarily relied on the available instrumental seismicity data and large historical earthquakes (see for example, Smith and Berryman 1986). However, historical records of seismicity are incomplete with respect to the much longer repeat times of large earthquakes on the major faults. Accordingly, fundamental to any comprehensive regional earthquake hazard study is the need to compile geological data (such as fault length, slip rate and paleoearthquake data) for all identified active faults capable of generating large earthquakes, and to then combine this with the comprehensive, high quality instrumental seismicity database as well as historical information on large, damaging earthquakes. Such a multi-disciplinary geological and seismological database is now providing the basis for Probabilistic Seismic Hazard Modeling (Working Group of California Earthquake Probabilities 1995; Stirling et al. 1998;
Stirling et al. this volume).

Fault-specific earthquake source characterisation involves the quantification, as far as is practicable, of the size(s) of earthquakes that a fault may generate by way of periodic strain release, and also the quantification of the distribution of these earthquakes in both space and time, as well as the mechanism of faulting. As such, earthquake source characterisation can be used to provide the basis for evaluating the long-term earthquake hazard for a particular site or region (e.g. Stirling et al. 1998). A critical aspect of earthquake source characterisation is the observation from those historic large earthquakes accompanied by surface rupture, that an earthquake on a major fault does not necessarily rupture the entire length of the fault, but only a portion or segment of that fault. The boundaries or barriers between these rupture segments typically coincide with major structural discontinuities along a fault trace or zone, such as bends or step-overs, and intersections with other faults (for example Schwartz and Coppersmith 1986; Sibson 1989; Scholz 1990; McCalpin 1996a). In more recent years detailed fault-specific geological studies have demonstrated that individual pre-historic large earthquake rupture events can be identified by analysis of the micro-topography and associated Late Quaternary deposits (e.g. Cowan and McGlone 1991). In addition where a detailed geological record is available the timing between successive events may also be constrained. Such investigation of pre-historic earthquakes has developed into a formal discipline known as paleoseismology (Wallace 1981; McCalpin 1996a).

Paleoseismic investigations along major fault zones have confirmed the importance of the segmentation model with respect to earthquake source recognition (see for example Sieh 1984; Schwartz and Coppersmith 1984, 1986). In addition, such detailed geological investigations have yielded paleoseismic information on fault slip rates, recurrence intervals, the amount of displacement per event and the elapsed time since the most recent rupture. Over the last two decades, as more paleoseismic data on large earthquakes has become available, and in combination with the much shorter instrumental seismicity catalogue, better earthquake recurrence models and earthquake hazard models using a probabilistic approach, have been developed.

Identification of the segments of a major fault that behave as independent earthquake sources is an essential first step in any seismic hazard evaluation for any region because they control the location, size, and periodicity of future major damaging earthquakes.

Recognition of fault zone segmentation primarily requires sufficiently detailed geological field mapping which must document in particular the structures associated with Late Quaternary active earth deformation. This in turn can be supplemented, when available, with a high quality instrumental seismicity database in order to better define major fault segments and their sub-surface geometry and extent, and likely to represent seismogenic source structures. Structural segmentation is not necessarily permanent nor is it definitive in terms of rupture extent. A paleoseismic history of earthquake rupture activity along segmented faults is required to compliment and confirm such modeling. Until recently such a paleoseimic database was mostly unavailable for most major faults in New Zealand. However, over the 
last decade significant advances in terms of the paleoseismic database for the Canterbury and surrounding regions of South Island have been achieved, and a significant body of new data is now available, provided by the long-term research programmes conducted by the Department of Geological Sciences of the University of Canterbury and the Institute of Geological and Nuclear Sciences.

In the absence of historic large magnitude earthquake ruptures associated with identified earthquake source structures, any estimation of maximum earthquake magnitude for specific fault segments must be based on empirical correlations between surface rupture length or displacement per event and magnitude (e.g. Bonilla et al. 1984; Wells and Coppersmith 1994; Anderson et al. 1996). Other physical variables relating to fault zone geometry and kinematics, rock properties, and earthquake rupture processes may also be important in determining earthquake magnitude, but in the absence of a more comprehensive historic rupture record the empirical relationship have been widely adopted. Elder et al. (1991) provide a more detailed discussion of the limitations with respect to such empirical approaches.

For the purpose of this study we have, where available, summarised relevant fault specific data about segment lengths and single event displacements (refer Tables 1-8). Where previous workers have estimated possible maximum earthquake magnitudes we have included this information. For earthquake source structures identified in this study, but not previously studied, or for which there is no reliable paleoseismic or fault geometry data, we have included an estimate for maximum earthquake magnitude based on segment length and or longterm slip rates. Magnitude assignments are based on the criteria used by Wells and Coppersmith (1994), and Anderson et al. (1996).

As previously noted, despite significant advances over the last decade in terms of identification of earthquake sources in the Canterbury region, more detailed characterisation in terms of paleoseimic data is still lacking for many Late Quaternary active tectonic structures.

Details on fault type, geometry, and activity for all known earthquake source structures are included with the more comprehensive GIS database held by Environment Canterbury, and are based on the maps prepared at scales of 1:250,000 and 1:50,000 which accompanied the Stage 1 (Part A) report (Pettinga et al. 1998). Approximately ninety such tectonic structures are recognised, while many of the mapped fault zones are comprised of more than one geologically recent trace or segment.

\section{MAJOR EARTHQUAKE SOURCES FOR THE CANTERBURY REGION}

Despite the absence of major damaging earthquakes in Canterbury for more than 70 years it is clear from the historical record and from regional geological studies that Canterbury lies within a zone capable of generating large and relatively frequent earthquakes. The 18 June 1994 magnitude 6.7 Arthurs Pass Earthquake, and its associated aftershock sequence reflects not only the ongoing tectonic activity, but also its complexity (Abercrombie et al. 2000). Seismic hazard assessment in the Canterbury region must not only take into account the activity of the mapped onshore faults and fault propagated folds within the region, but also of the hazards contributed by active geological structures in the adjacent regions of Otago, Westland and Marlborough, and of those located beneath Pegasus Bay and offshore to the east of the South Island. Effectively, because of the geographic extent of the Canterbury region, a large earthquake anywhere in the South Island may impact on the region.

\section{PRESENT-DAY PLATE BOUNDARY TECTONIC SETTING OF NEW ZEALAND}

The largely submerged New Zealand micro-continent straddles the Australia-Pacific plate boundary zone, and the relative motion of these plates has controlled the upper Cenozoic (last 5-10 million years) evolution and present shape of the emergent New Zealand landmass (Figure 1). The major features of the South Island plate boundary zone include the Alpine fault and the Marlborough Fault Zone, these together have long been recognised as an oblique-slip trench-trench transform, linking opposite dipping obliquely convergent subduction zones, including the Pliocene $(\sim 5$ Myr) initiated west-facing Puysegur trench to the SW, and the late Oligocene-Miocene $(\sim 25 \mathrm{Myr})$ initiated east-facing Kermadec-Hikurangi trench to the NE. The Hikurangi subduction zone extends south from East Cape to offshore near Kaikoura. The subducted slab of the Pacific lithospheric plate is well imaged by ongoing seismicity (Anderson and Webb 1994).

The Alpine fault forms a linear feature extending onshore for about $420 \mathrm{~km}$ along the west side of South Island (Berryman et al. 1992). Recent offshore studies detail evidence that it may extend for a further $200 \mathrm{~km}$ to the southwest tip of Fiordland (Delteil et al. 1996). Generally the fault is an east dipping oblique shear. In central Westland it is complexly segmented at the near surface into oblique thrust sections linked by sub-vertical dextral tear faults which also strike parallel to the present plate convergence vector (Norris et al. 1990; Berryman et al. 1992; Yetton 2000). Bands of highgrade metamorphic rocks lie parallel and adjacent to the fault, reflecting substantial long-term upper Cenozoic uplift of the eastern or Pacific plate side. Projection of this eastward dip on the Alpine fault is still uncertain (Davey et al. 1995), but new geophysical data (Kleffman et al. 1998) documents evidence that the fault may flatten to the east at depth in the lower crust, and extends beneath west Canterbury.

Geodetic and geologic data show that at least $70-75 \%$ of the plate boundary motion is accommodated along the narrow high strain zone associated with the Alpine fault (Norris et al. 1990; Berryman et al. 1992; Walcott 1998; Norris and Cooper 2001). The remainder of the oblique plate motion is distributed across the $150-200 \mathrm{~km}$ wide Southern Alps into the Canterbury region. This wider zone of lower strain plate deformation is best modeled in terms of a two-sided deforming wedge, associated with an inferred lower crustal delamination (Norris et al. 1990)(Figure 2). Structural styles of faulting and folding to the east side indicate a complex pattern of strain partitioning is occurring in the upper crust. The fault controlled eastern foothills rangefront of the Southern Alps, with numerous re-entrants, is complexly segmented also, and rises abruptly above Late Cenozoic gravels of the Canterbury Plains. 


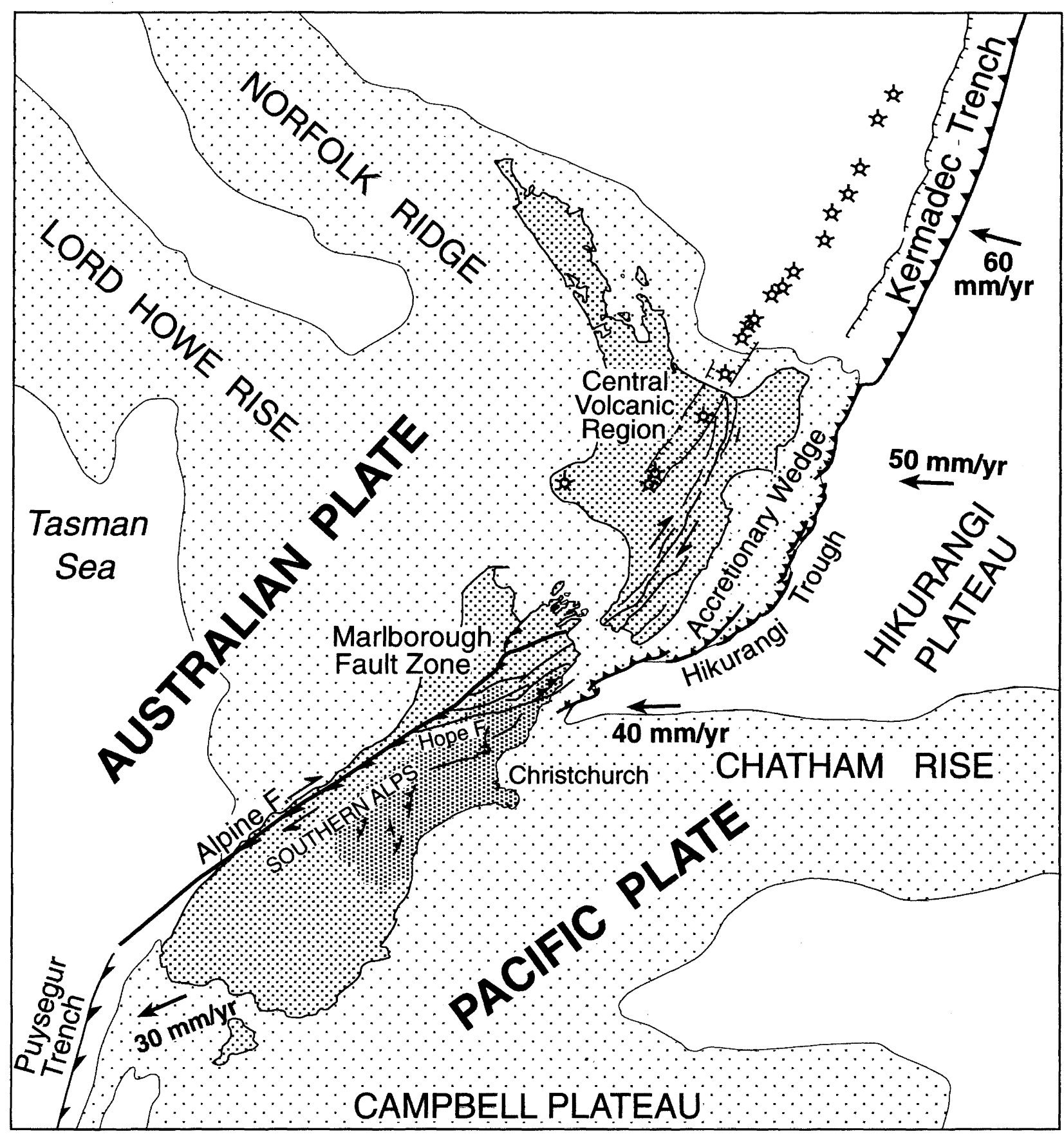

Continental crust

Oceanic crust

Figure 1: Tectonic setting and main structural features of the New Zealand micro-continent straddling the obliquely convergent Australia-Pacific plate boundary zone. Numbered arrows show rates of relative convergence in mm/year (from deMets et al. 1990). Canterbury region is indicated by darker stiple shading. $(F)=$ fault. 


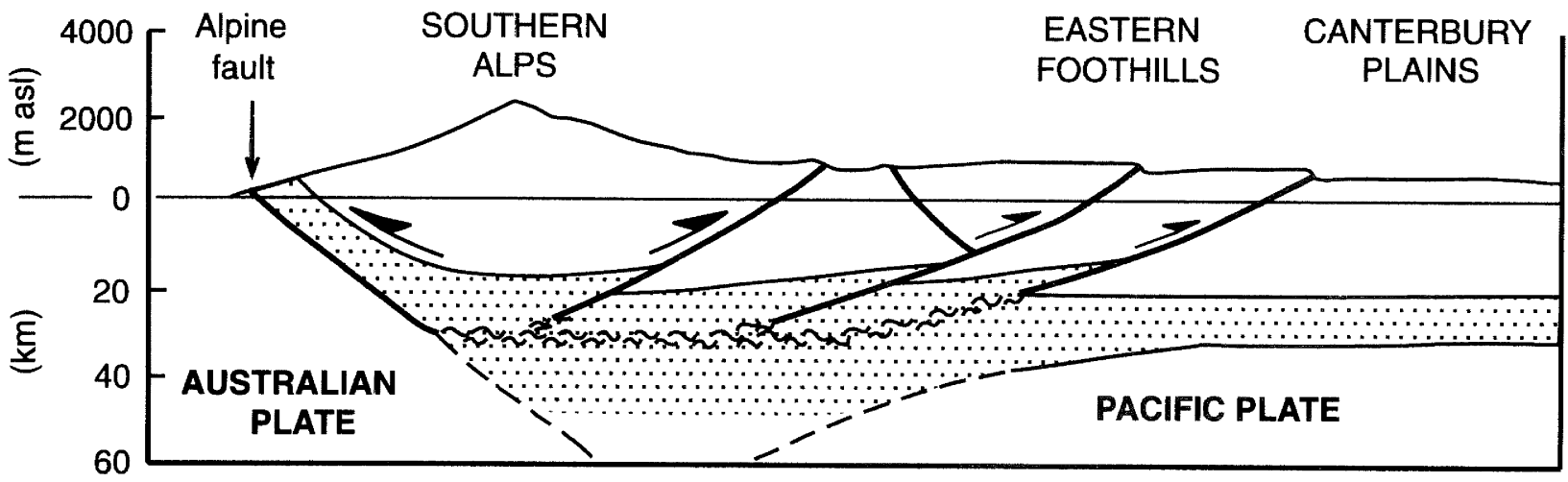

Figure 2: Schematic diagram of the two-sided deforming wedge model representing the oblique continent-continent collision zone of the Australia-Pacific plate boundary across central South Island. Note the inferred crustal delamination associated with the projected Alpine fault to mid and lower crustal levels. Shading represents lower crustal rocks. Figure modified after Norris et al. (1990) and Kleffman et al. (1998). Note scale change from above to below sealevel.

\section{ACTIVE TECTONIC SETTING OF THE CANTERBURY REGION}

Much of the Canterbury region is located within the wide zone of active earth deformation associated with the oblique collision between the Australian and Pacific tectonic plates east of the Alpine fault (Figures 3 and 4). The present day tectonic tempo of active earth deformation is greatest along the narrow zone adjacent to the Alpine fault, and where the plate boundary zone transfers across South Island, through the Marlborough and north Canterbury areas to link with the offshore trench and subduction zone from near Kaikoura (Van Dissen and Yeats 1991; Lewis and Pettinga 1993; Barnes 1993; Barnes 1996; Barnes et al. 1998). In the north Canterbury region the southward transition from oblique subduction to oblique continental collision is associated with tectonic shortening, crustal thickening and uplift. Landforms reflect the ongoing nature of this active earth deformation (e.g. Nicol 1991; Cowan 1992; Wood et al. 1994; Pettinga and Armstrong 1998; Eusden et al. 2000), and also reveal that the Australia-Pacific plate boundary zone has progressively widened here, and continues to do so, during the Late Quaternary (Nicol 1991; Cowan 1992). East of the main divide of the Southern Alps, in central and south Canterbury, the rate of tectonic deformation progressively diminishes to the southeast.

Associated seismicity is widespread (Reyners 1989; Cowan 1992; Anderson and Webb 1994; Eberhart-Phillips 1995; Eberhart-Phillips and Reyners 1997) (Figures 5 and 6). Since 1850 several large shallow earthquakes (magnitude greater than 6.5 , and at depths of less than $15 \mathrm{~km}$ ), as well as thousands of smaller earthquakes have occurred across this northern and central parts of South Island. New data indicates that the Alpine fault is not aseismic, as previously suggested by other workers. Diffuse seismicity extends for over $70 \mathrm{~km}$ to the SE of the fault, with focal depths ranging from $10 \mathrm{~km}$ near the Alpine fault to more than $20 \mathrm{~km}$ away from the fault (Eberhart-Phillips 1995).
Beneath north Canterbury focal mechanisms of upper and lower crustal earthquakes indicate variations occur in strain above and below an aseismic zone in the mid-crust, as well as changes in subducting plate geometry and the seismic strain regime (Cowan 1992; Reyners and Cowan 1993; Reyners 1998). The upper crust in this the plate boundary transfer zone thus appears to be composed of two kinematically distinct layers: i). an uppermost crustal zone of discontinuous faults, where fault slip vectors are variable, but are generally not parallel to the plate motion and reflect volumetric and spatial constraints imposed by adjacent blocks; and ii). a deeper zone of crustal deformation, reflected at the surface only by major structures like the Alpine and Hope faults, that appear to be undergoing translation parallel to plate motion (Pettinga and Wise 1994). In a detailed analysis of seismicity data acquired by a dense regional network of portable seismographs, Reyners (1998) concluded that the subduction interface beneath Marlborough and north Canterbury is now permanently locked, and that large subduction thrust events are not expected in this area. Nonetheless, the subducted slab continues to have a seismic signature.

The upper crustal geological structure of the Canterbury region in the north is dominated by north and northeast trending active faults and folds that accommodate the transfer of relative plate motion between the Hikurangi Trench and the Alpine fault. For the central and south Canterbury region, structures are generally more northerly trending, and are forming in response to the continent-continent collision zone along the eastern side of the deforming wedge of the Southern Alps. The locations of the principal faults and folds that offset and/or deform surface geological and geomorphological features of Late Quaternary age in and adjacent to the Canterbury region of the South Island are depicted in Figure 3. The following section outlines our approach to the grouping of these active structures in order to provide a basis for regional earthquake hazard assessment (see Stirling et al. this volume). 


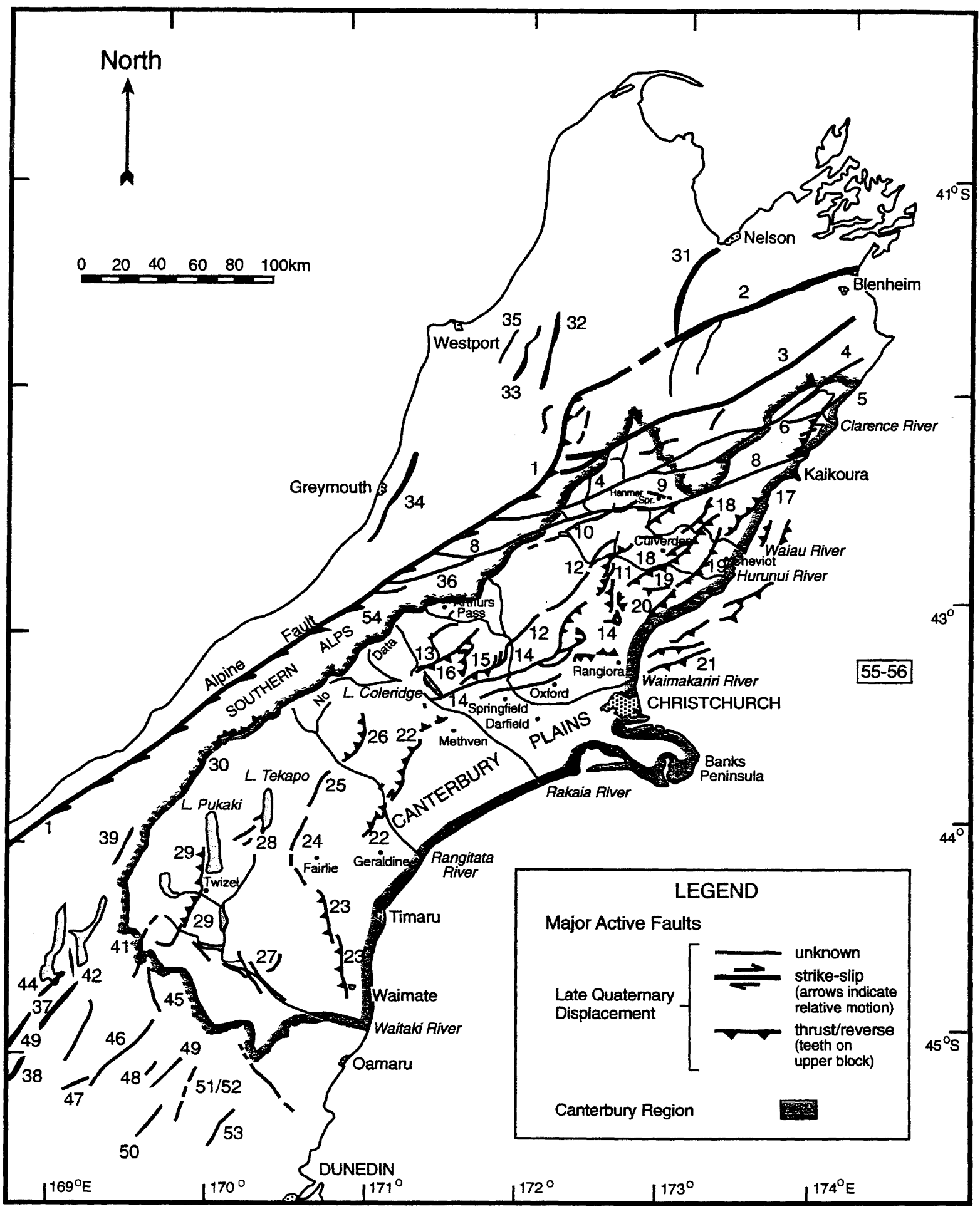

Figure 3: Summary map of the known major active earthquake source faults and folds in the Canterbury region (for divisions of region into structural domains refer figure 4). (1) Alpine fault; (2) Wairau fault; (3) Awatere fault; (4) Clarence fault; (5) Kekerengu fault; (6) Fidget fault; (7) Jordan fault; (8) Hope fault; (9) Hanmer fault; (10) Kakapo fault; (11) West Culverden Fault Zone (includes the Mt Arden fault, Tommys Stream fault, Waitohi Downs fault, and Balmoral fault; (12) Esk fault; (13) Harper fault; (14) Porters Pass-Amberley Fault Zone (includes the Mt Grey fault, Mt Thomas fault, Lees Valley fault, Townshend fault, Glentui fault, Coopers Creek fault, Porters Pass fault, Ashley fault; (15) Torlesse fault; (16) Cheeseman Fault Zone; (17) Hundalee fault; (18) Lowry Peaks Fault Zone (includes the Lowry Peaks fault, Leonard Mound fault, and Hurunui Bluff fault); (19) Kaiwara fault; (20) Omihi fault; (21) Pegasus Bay fault; (22) Mt Hutt-Mt Peel Fault Zone; (23) Hunters Hills Fault Zone; (24) Fairlie Fault Zone; (25) Fox Peak Fault Zone; (26) Lake Heron fault; (27) Dryburgh/Waitangi/Wharekuri/Kirkliston faults; (28) Irishman Creek Fault Zone; (29) Ostler fault; (30) Main Divide Fault Zone. Faults numbered $31-56$ are located outside the Canterbury region (see Table 8). 


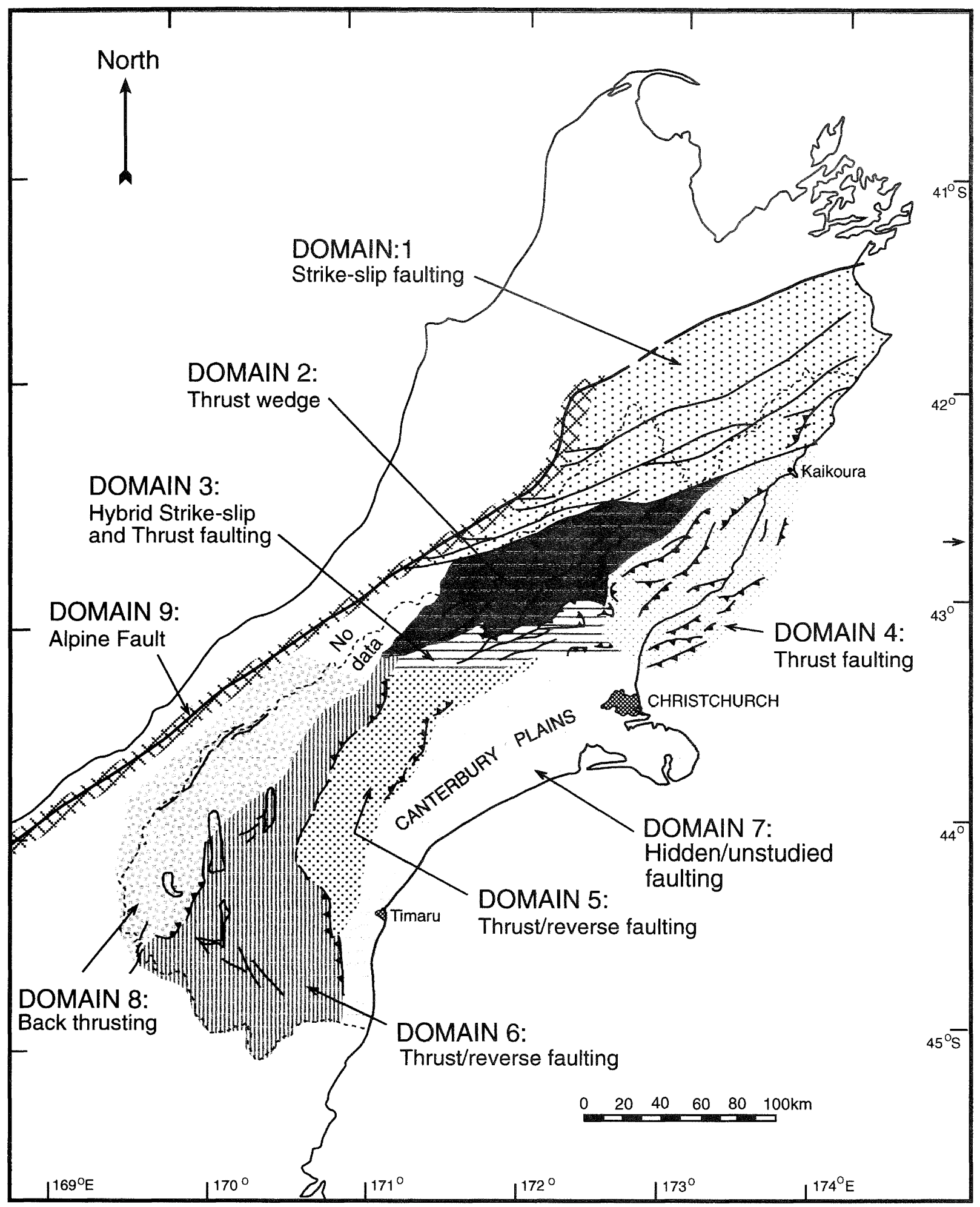

Figure 4: Summary map of the structural domains 1-8 for the Canterbury region, and structural domain 9 for the Alpine fault outside the Canterbury region. Figure is based on more detailed data presented in Figure 3. Refer to text for more detailed discussion. Domain 1: Marlborough Fault Zone; Domain 2: West Culverden Fault Zone; Domain 3: Porters Pass-Amberley Fault Zone; Domain 4: North Canterbury Fold and Thrust Belt; Domain 5: Mt Hutt-Mt Peel Fault Zone; Domain 6: South Canterbury Zone; Domain 7: Canterbury Plains Zone; Domain 8: Southern Alps Zone; Domain 9: Alpine Fault Zone. 


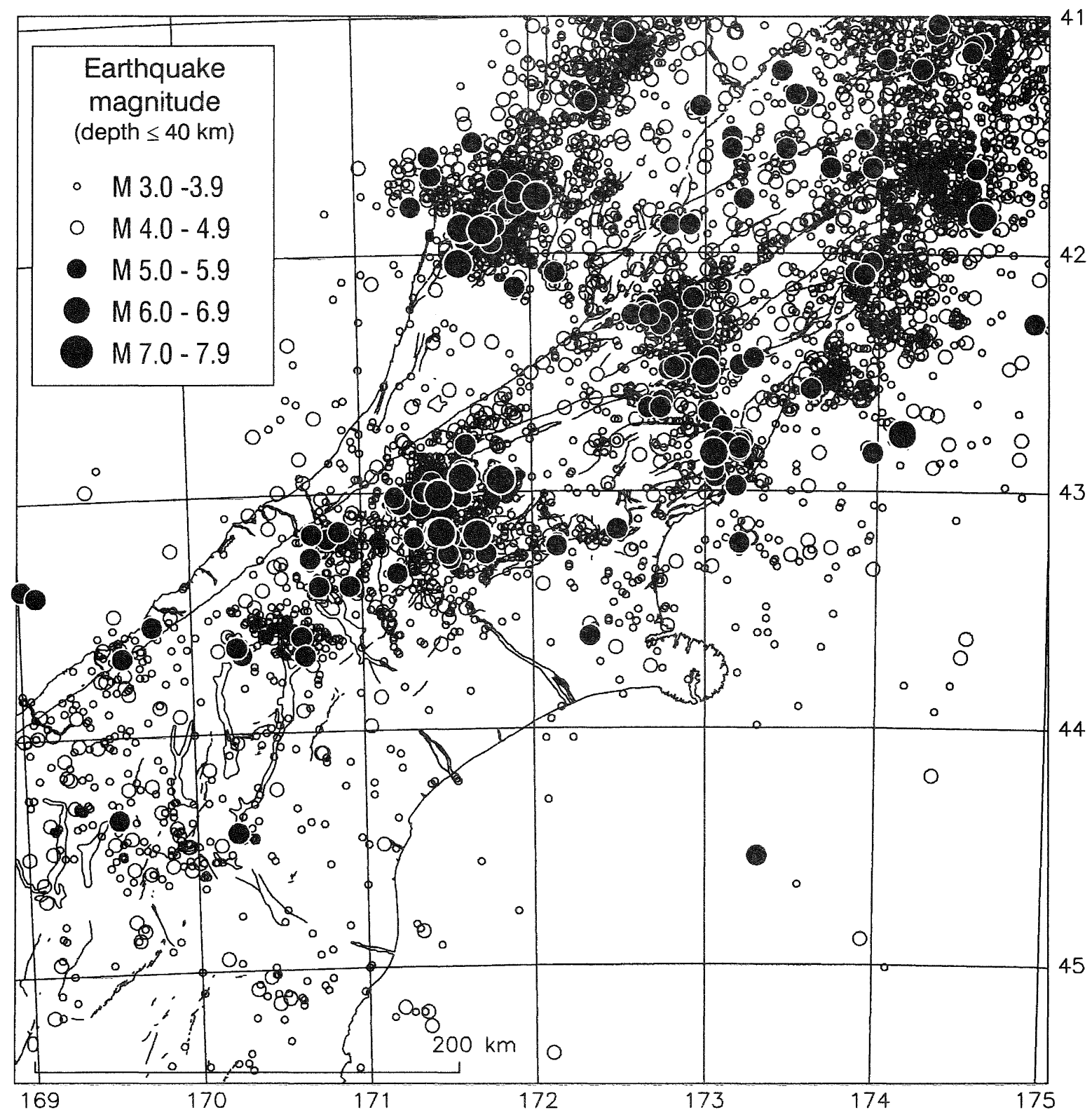

Figure 5: Regional seismicity from instrumental records for Canterbury and surrounding regions, 1943-1997. 


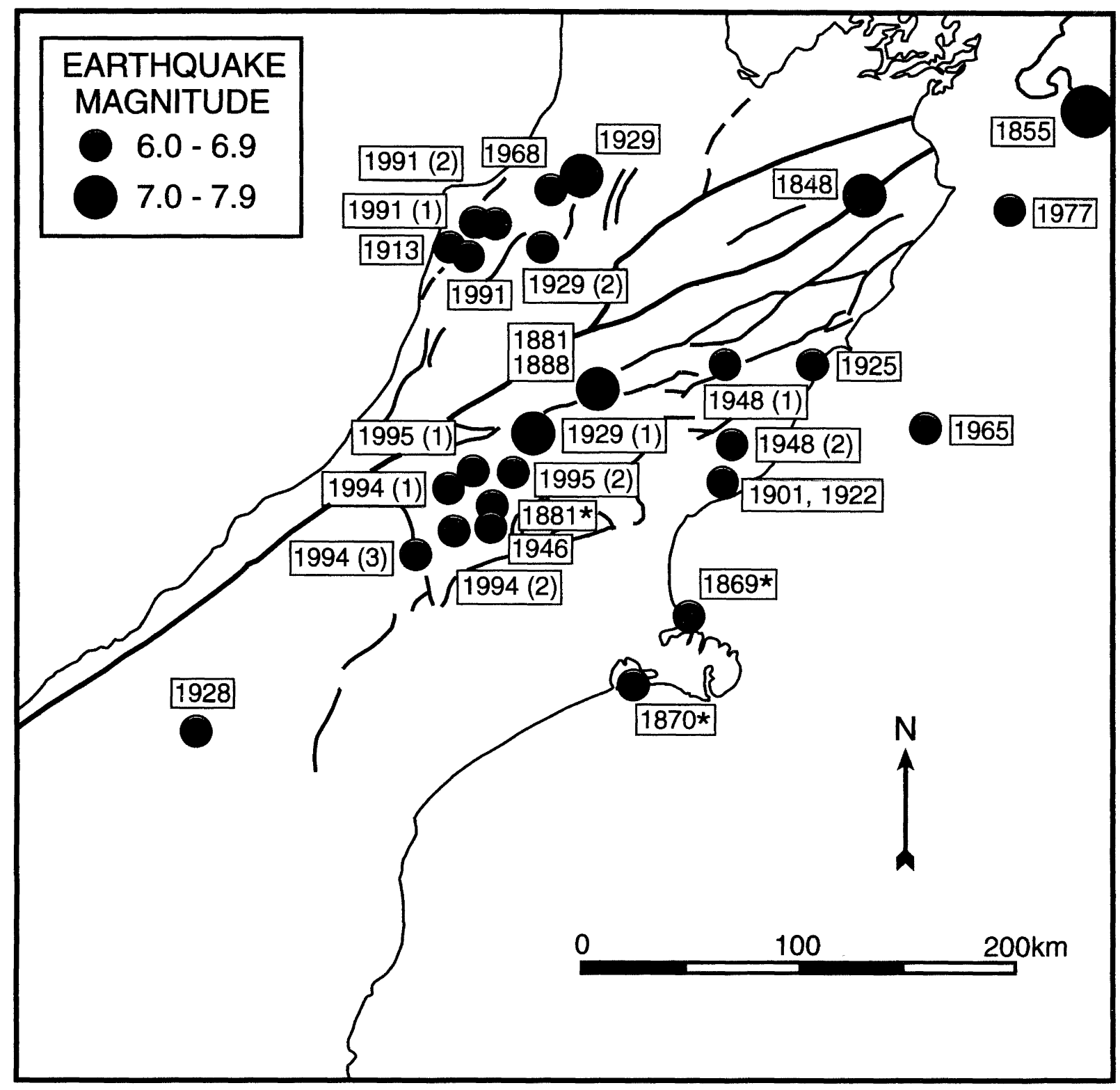

Figure 6: Historic record of large earthquakes impacting the Canterbury region. Map depicts epicentres of all Magnitude 6 and above earthquakes within, or close to the Canterbury region (1840-1997), and also the epicentres of large earthquakes that occurred well outside the region, some of which were responsible for causing intensities of MM6 or greater over a wide area within the Canterbury region. Epicentres for the three events identified by the $\left({ }^{*}\right)$ have been relocated on the basis of new data presented in Stirling et al. (1999). 


\section{STRUCTURAL DOMAINS AND THEIR MAJOR EARTHQUAKE SOURCES FOR THE CANTERBURY REGION}

For the purpose of this study we establish and describe here eight distinct structural domains within which individual geological (i.e. earthquake generating) structures are fundamentally related both in terms of their tectonic setting, style, geometry and rates of deformation with respect to the plate boundary zone (Figure 4) (refer also to Tables 1-7). Faults and folds in adjacent structural domains commonly vary in strike, and many accommodate oblique slip, this is especially so for the northern part of the Canterbury region. The spatial relationships and kinematics of faulting reflects the complex pattern of strain that is indicative of thin-skinned, upper crustal deformation. A ninth structural domain encompassing the Alpine fault is defined also in a following section, but lies outside the Canterbury region.

The domains are geologically established in order to provide the basis for probabilistic seismic hazard assessment, presented in the following companion paper (Stirling et al. this volume). A number of significant studies of earth deformation to determine the location, nature and rates of movement on active faults and folds, as well as fault specific paleoseismic investigations have been undertaken in Canterbury and surrounding areas in recent years by a number of researchers and organizations. Key data from these studies are also summarised for each of our structural domains. Fault parameters are detailed in the accompanying Tables 1-8. More detailed discussion is also available in the original report prepared for Environment Canterbury (see Pettinga et al. 1998).

Domain 1 - Marlborough Fault Zone: This domain includes the major system of NE trending strike-slip faults (Hope, Clarence, Awatere and Wairau), which near their SW and NE terminations splay and form a series of imbricate oblique reverse/thrust faults. Along the Kaikoura coast, both north and south of the Hope fault, adjacent thrust faults dip mainly due west, and serve to dissipate motion on the Hope fault, so accommodating crustal shortening (telescoping) associated with oblique plate collision and associated subduction of Pacific plate. Barnes and Audru (1999) have also documented the continuation of a strand of the Hope fault offshore, to the northeast, as it links with a complex array of active structures off the Marlborough coast.

The Marlborough Fault Zone is the most active earth deformation zone in the Canterbury region. Deformation in Marlborough is primarily accommodated by these major dextral strike-slip elements of the Marlborough Fault Zone (Figures 3 and 4). The Late Quaternary slip rates on these faults increases north to south, from $3-5 \mathrm{~mm} /$ year on the Wairau-Alpine fault (e.g. Lensen 1968; Campbell 1973), 5-8 $\mathrm{mm} /$ year on the Awatere fault (McCalpin 1996b; Little et al. 1998). The Clarence fault slip rates, based on the work of Kieckhefer (1979) and Van Dissen and Nicol (1998), are 3.5$5.0 \mathrm{~mm} /$ year over the last $10-18,000$ years. The Hope fault carries by far the highest slip rates of all the Marlborough faults, ranging from $10-14 \mathrm{~mm} /$ year for the Hope River segment (Cowan, 1989 and 1990), to as high as 11-35 $\mathrm{mm} /$ year for the Conway-Kahutara segment (Freund 1971; Knuepfer 1984; 1992; Van Dissen 1989; Bull 1991; McMorran 1991; Pope 1994). Each of the major faults and their component segments are clearly delineated from geological field mapping, and field relationships are indicative of a Holocene earthquake rupture history. If the major faults are seismogenically segmented, then at least 13 earthquake sources are identified within Structural Domain 1, and their source parameters are summarised in Table 1. A more detailed review of each of the major seismogenic source faults in the Marlborough Fault Zone (Domain 1) is included in Pettinga et al. (1998).

The current understanding of slip rates across the domain, from north to south, indicates a gradual temporal southward migration in the loci of strike-slip displacement during the late Quaternary, while the Hope fault currently carries the highest slip rates. The summed minimum to maximum slip rate values across the Marlborough Fault Zone are $~ 30-54$ $\mathrm{mm} /$ year. The currently accepted rate of plate convergence is about $40 \mathrm{~mm} /$ year (DeMets et al. 1990), providing some constraint to the allowable summed maximum slip-rate accommodated across the Marlborough Fault Zone. Clearly there is a complex temporal and spatial variation in slip rate values. While the main Marlborough faults, and more specifically the Hope fault, accommodate a significant component of the total plate rate, there is also a much wider zone of associated active earth deformation forming in response to the transfer of the plate boundary across the South Island to the Alpine fault. The evidence indicative of this wider zone of deformation in the Canterbury region is presented in the following section (Domains 2-8).

A number of site-specific paleoseismic investigations have been completed on the faults of the Marlborough Fault Zone (e.g. Cowan 1991; Cowan and McGlone 1991; Grapes et al. 1998; McCalpin 1996b; McMorran 1991; Pope 1994; Simpson 1995). Data from these studies are summarised in Table 1. For a more detailed review and discussion of the paleoseismic data the reader is referred to Pettinga et al. (1998).

Domain 2 - West Culverden Fault Zone: This domain includes a west dipping system of thrusts and/or reverse faults and associated fault propagated folds, mapped to the west of Culverden Basin. This rangefront system of faults represents the eastern margin of a wedge-shaped structural domain that defines the eastern margin of the Southern Alps in north Canterbury. This system of faults and associated deformation are interpreted as back-thrusts off the east dipping Alpine fault zone inferred to extend to mid and lower crustal depths beneath the Southern Alps. The major NE trending faults, such as the Harper and Esk, are interpreted to represent earlier rangefront fault systems associated with a narrower plate boundary zone across the region during the Early Pleistocene (Cowan 1992), and clearly continue to be active into the Late Pleistocene and/or Holocene.

Culverden Basin is a broad northeast trending structural depression about $55 \mathrm{~km}$ long, by $17 \mathrm{~km}$ wide, floored by extensive coalescing fan aggradation surfaces formed by several major rivers cutting across the basin axis in antecedent courses (Armstrong 2000). Culverden Basin is situated between two contrasting structural domains (Figure 
Table 1: Earthquake Source Parameters for Domain 1

\begin{tabular}{|c|c|c|c|c|c|c|c|c|c|}
\hline $\begin{array}{c}\text { Fault } \\
\text { Number } \\
\left(_{(*)}\right.\end{array}$ & Fault Name & Fault Type $^{(t)}$ & $\begin{array}{l}\text { Interpreted } \\
\text { Dip Angle } \\
\text { (deg) }\end{array}$ & $\begin{array}{c}\text { Length } \\
(\mathrm{km})\end{array}$ & $\begin{array}{c}\text { Average } \\
\text { Displacement / } \\
\text { event }(\mathbf{m})\end{array}$ & $\begin{array}{l}\text { Slip Rates } \\
\text { (mm/year) }\end{array}$ & $\begin{array}{c}\text { Last Rupture(s) } \\
\text { (years) }\end{array}$ & $\begin{array}{c}\text { Recurrence } \\
\text { Intervals }{ }^{(* \star)} \\
\text { (years) }\end{array}$ & $\begin{array}{l}\text { Magnitude } \\
\text { (Mw) }\end{array}$ \\
\hline 2 & Wairau Fault & SS & $70-90$ & $110-120$ & $5-7$ & $3-5$ & $\begin{array}{c}- \\
>800^{(1)}\end{array}$ & $1000-2300$ & 7.6 \\
\hline \multirow[t]{3}{*}{3} & Awatere Fault & & & & & & - & & \\
\hline & North Segment & SS & $70-90$ & 143 & $5.5-7.5$ & $5-8(6.5)$ & $150^{(3)}$ & $\begin{array}{c}690-1500 \\
(1000)\end{array}$ & 7.5 \\
\hline & South Segment & SS & $70-90$ & 92 & - & $\begin{array}{c}2.6-13.7 \\
(8)\end{array}$ & $\begin{array}{c}522-597^{(1)} \\
2500-4500^{(2)}\end{array}$ & $1929-3931$ & 7.5 \\
\hline \multirow[t]{3}{*}{4} & Clarence Fault & & & & - & & - & & \\
\hline & North Segment & SS/Rev & $60-80$ & 122 & $\sim 7$ & $4-7$ & - & 1500 & 7.7 \\
\hline & South Segment & SS & $70-90$ & 128 & $\begin{array}{l}3.6-11 \\
(7)\end{array}$ & $4-8$ & - & $\begin{array}{l}490-2750 \\
(1080)\end{array}$ & \\
\hline 5 & Kekerengu Fault & SS/Rev & $60-90 N W$ & 35 & $\begin{array}{l}3.5-7 \\
(5.5)\end{array}$ & $5-10$ & - & $\begin{array}{c}350-1500 \\
(730)\end{array}$ & 7.2 \\
\hline 6 & Fidget Fault & SS & $70-90$ & $20-25$ & - & - & - & - & \\
\hline 7 & Jordan Thrust Fault & Rev & $25-50 \mathrm{NW}$ & 25 & $2-4$ & $\begin{array}{l}\text { v } 1.3-2.5 \text {; } \\
\text { h } 1.0-3.4\end{array}$ & - & 1200 & 7.1 \\
\hline \multirow[t]{4}{*}{8} & Hope Fault & & & & & & & & \\
\hline & Hope R.-Taramakau S. & SS & $70-90$ & 72 & $2-4$ & $\begin{array}{l}14 \pm 3 \& \\
10 \pm 0.5\end{array}$ & $\begin{array}{c}110^{(3)} ; \pm 1745^{(4)} \\
\pm 1602^{(4)} ; \pm 1459^{(4)} \\
\pm 1316^{4}\end{array}$ & $81-200$ & 7.3 \\
\hline & 1888 Rupture & SS & $70-90$ & 38 & $1.5-2.6$ & - & $100^{(3)}$ & 120 & 7.2 \\
\hline & Conway-Offshore $S$. & SS/Rev & $60-90 N W$ & 120 & - & $11-35$ & $1838^{(4,5)} ;<1000^{(2)}$ & $120-300(200)$ & 7.6 \\
\hline 9 & Hanmer Fault & $\mathrm{N} / \mathrm{SS}$ & $50-70 \mathrm{~S}$ & 28 & $1-3$ & $1-2$ & $<10,000^{(2)}$ & 1000 & 6.9 \\
\hline 10 & Kakapo Fault & SS & $70-90$ & 87 & - & $4.4-8.4$ & $<10,000^{(2)}$ & $300-700(500)$ & 7.3 \\
\hline
\end{tabular}

Footnotes: $\quad\left({ }^{*}\right)$ : For location of faults and index to fault numbers refer to Figure 3.

(\#) : Fault type abbreviations: ss - strike-slip; rev - reverse/thrust; $\mathrm{n}$ - normal. $(* *)$ : Based on paleoseismic data.

$\left.{ }^{1}\right): \mathrm{C}^{14}$ dates expressed as years B.P. are given prior to 1950 , and are only

$\left.{ }^{2}\right)$ : relative chronology only

$\left({ }^{4}\right)$ : Given as years $\mathrm{AD}$

approximate to calendar years. The relationship is not constant through time

$\left.{ }^{3}\right)$ : Historic rupture event

$\left({ }^{5}\right)$ : Based on lichenometric date. 
4: Domains $2 \& 4$ ). It is flanked on both the west and east sides by converging thrust fault systems that merge together at the southern end of the basin and provide structural closure to the depression. Culverden Basin structure is further complicated by active structures cutting across the basin floor in the form of actively growing anticlines and faults which splay off the basin bounding fault systems at high angles (Pettinga and Armstrong, 1998; Armstrong, 2000). Effectively Culverden Basin represents a remnant faultbounded area of relatively less deformed upper crust in north Canterbury, across which the Hikurangi subduction-driven thrust deformation to the east (Domain 4) is encroaching near to the back-thrust driven deformation off the Alpine fault system (Domain 2), along the west margin of the basin. At the southern end of Culverden Basin these two systems are directly interacting, creating considerable structural complexity expressed by interference folding and orthogonal thrust systems (Nicol 1991; Litchfield 1995).

Rates of active earth deformation in Structural Domain 2 are relatively subdued. The only documented structure with evidence for repeated Holocene rupture is the Balmoral fault. Sinistral slip rates on this oblique fault are relatively low, $<2$ $\mathrm{mm} /$ year (Mould 1992). The Balmoral fault appears to be the latest phase of outward propagation of the imbricate rangefront thrust system. Earthquake source parameters for the major faults located in Domain 2 are summarised in Table 2.

The Esk fault, with its possible connection through to the east-west trending Culverden fault, may represent a previous rangefront system to the western side of Culverden Basin. However, no detailed or recent reconnaissance mapping of this system of faults has been conducted, and we are not able to assess the activity of the Esk-Culverden fault system further here. The topographic step up to the west of the inferred location of this fault zone is indicative of significant Late Quaternary tectonic uplift.

Only limited site-specific paleoseismic investigations have been completed on faults in Domain 2. Data are summarised in Table 2. For a more detailed review and discussion of the paleoseismic data the reader is referred to Pettinga et al. (1998).

Domain 3 - Porters Pass-Amberley Fault Zone: The Southern Alps foothills and rangefront along the northwest margin of the Canterbury Plains, are evolving in response to a hybrid system of interconnected east-northeast trending strike-slip transfer faults, oblique thrust and/or reverse faults with associated faultpropagated folds. The Porters Pass-Amberley Fault Zone is a juvenile fault system reflecting the latest phase of plate boundary zone widening in the late Pleistocene (Cowan 1992; Cowan et al. 1996). Further to the west, behind this rangefront, structurally deeper levels are exposed and disseminated oblique strike-slip faulting dominates late Quaternary deformation.

The Porters Pass-Amberley Fault Zone extends east-northeast from the Lake Coleridge area in the south, along the Southern Alps foothills and the northwestern margin of the Canterbury Plains to northeast near Amberley and Waipara (Cowan 1992; Nicol et al. 1994; Cowan et al. 1996) (Figures 3 and 4). This broad zone of active earth deformation includes a number of major individual fault elements, which are complexly interconnected. Research projects completed by
Nicol (1991), Cowan (1992), and Garlick (1992) have for the first time documented and analysed this major fault zone in some detail. These geological studies have concentrated on the dating of landscape features disrupted by faulting, such as river terraces, landslides, and alluvial fans that have been deformed by fault movements accompanying large prehistoric earthquakes. The long-term result of such episodic earth movements is reflected by the development of the hill country and mountains in Canterbury. An estimate for the total offset across the Porters Pass-Amberley Fault Zone has proved difficult to constrain. Cowan et al. (1996) infer less than 2 kilometres of dextral shear based on strike separation of Oligocene and Lower Miocene limestone beds across the Mount Grey block, and analysis of strike-slip related uplift across the restraining bend of the Mount Oxford block.

The various active fault strands of the Porters Pass-Amberley Fault Zone are delineated by a combination of zones of crushed and sheared Torlesse greywacke that strike east and northeast, as well as the disrupted Late Pleistocene and Holocene landforms. Active faults are mapped around the base of Mt. Grey, Mt. Thomas, Mt. Oxford, the Torlesse Range, Porters Pass, and east of Lake Coleridge. To the northwest, Lees Valley is fault bounded along its east margin by a major fault splay off the Porters Pass-Amberley Fault Zone. Indirect evidence also indicates active faults exist along the rangefront between Oxford and Springfield. Other active elements of the Porters Pass-Amberley Fault Zone are located east of the foothills range front, including the Cust and Ashley faults associated with the areas of uplift and folding giving rise to the Mairaki Downs hills, and the hillcountry of the Ashley forest. A summary of each of the major fault elements of the Porters Pass-Amberley Fault Zone is included in Pettinga et al. (1998).

Slip rates along the various strands of the Porters PassAmberley Fault Zone have proven difficult to constrain, but all previous workers report Holocene dextral slip rates of less than $5 \mathrm{~mm} /$ year (ranging from $\sim 0.5-5.0 \mathrm{~mm} / \mathrm{yr}$ ). Earthquake source parameters for the major faults located in Domain 3 are summarised in Table 3.

Within Structural Domain 3 the most active zone of earth deformation is the Porters Pass-Amberley Fault Zone. There are a minimum of 11 seismogenic structures, of which at least 5 are Holocene active. Cowan (1992) and Cowan et al. (1996) concluded that the Porters Pass fault had previously ruptured over a length of $70-100 \mathrm{~km}$, this would included rupture along 4 of the 5 Holocene active segments. However, it can not be discounted that rupture may occur on individual segments closely spaced in time, but associated with a series of lesser magnitude earthquakes, or that individual segments may rupture coseismically independently of the other nearby segments. Further research is needed to clarify the long-term behaviour of this newly formed zone of hybrid strike slip and thrust/reverse faulting.

Cowan et al. (1996) concluded that there is good paleoseismic evidence for two large $(M>7)$ earthquake ruptures during the last $\sim 2500$ years along the Porters PassAmberley Fault zone. Two earlier Holocene events were also identified by these authors, but provide only an incomplete record of repeated rupture of the fault zone. Based on these limited data a tentative return period of 1300-2000 years between large earthquakes is inferred, and this is consistent 
Table 2: Earthquake Source Parameters for Domain 2

\begin{tabular}{|c|c|c|c|c|c|c|c|c|c|}
\hline $\begin{array}{c}\text { Fault } \\
\text { Number } \\
\left(^{*}\right)\end{array}$ & Fault Name & Fault Type $^{(t)}$ & $\begin{array}{c}\text { Interpreted } \\
\text { Dip Angle } \\
\text { (deg) }\end{array}$ & $\begin{array}{l}\text { Length } \\
(\mathrm{km})\end{array}$ & $\begin{array}{c}\text { Average } \\
\text { Displacement / } \\
\text { event }(\mathrm{m})\end{array}$ & $\begin{array}{l}\text { Slip Rates } \\
\text { (mm/year) }\end{array}$ & $\begin{array}{c}\text { Last Rupture(s) } \\
\text { (years) }^{1,2}\end{array}$ & $\begin{array}{c}\text { Recurrence } \\
\text { Intervals }{ }^{(* *)} \\
\text { (years) }\end{array}$ & $\begin{array}{l}\text { Magnitude } \\
\text { (Mw) }\end{array}$ \\
\hline \multirow[t]{5}{*}{11} & West Culverden Fault Zone & $\operatorname{Rev}$ & $30-70 W$ & 24 & & 1 & $1495-1925^{(2)}$ & $5-10,000$ & 6.9 \\
\hline & Mt Arden Fault & Rev & $30-70 W$ & $6-10$ & - & - & - & - & \\
\hline & Tommys Stream Fault & $\operatorname{Rev}$ & $30-70 W$ & $10-15$ & - & - & - & - & \\
\hline & Waitohi Downs Fault & Rev & $30-70 W$ & $15-20$ & - & - & - & - & \\
\hline & Balmoral Fault & $\mathrm{Rev} / \mathrm{SS}$ & $30-70 \mathrm{~W}$ & $7-10$ & $2-6$ & $1-2$ & $1495-1925^{(2)}$ & $5-10,000$ & \\
\hline 12 & Esk Fault & $\operatorname{Rev} / \mathrm{SS}$ & $50-80 W$ & 71 & - & - & - & $5-10,000$ & 7.0 \\
\hline \multirow[t]{3}{*}{13} & Harper Fault & Rev & $20-50$ & 49 & & & $>10,000^{(2)}$ & $>10,000$ & 7.1 \\
\hline & West Harper & Rev & $20-50 \mathrm{NW}$ & $25-35$ & - & - & $>10,000^{(2)}$ & $>10,000$ & \\
\hline & East Harper & $\operatorname{Rev}$ & $20-50 \mathrm{SE}$ & $35-40$ & - & - & $>10,000^{(2)}$ & $>10,000$ & \\
\hline
\end{tabular}

Footnotes: $\left({ }^{*}\right)$ : For location of faults and index to fault numbers refer to Figure 3 . $\left({ }^{* *}\right)$ : Based on paleoseismic and/or slip rate data.

$\left({ }^{2}\right)$ : relative chronology only
(\#) : Fault type abbreviations: ss - strike-slip; rev - reverse/thrust; $\mathrm{n}$ - normal. (') : $\mathrm{C}^{14}$ dates expressed as years B.P. are given prior to 1950 , and are only approximate to calendar years. The relationship is not constant through time. 
Table 3: Earthquake Source Parameters for Domain 3

\begin{tabular}{|c|c|c|c|c|c|c|c|c|c|}
\hline $\begin{array}{c}\text { Fault } \\
\text { Number } \\
(*)\end{array}$ & Fault Name & Fault Type $^{(/)}$ & $\begin{array}{c}\text { Interpreted } \\
\text { Dip Angle } \\
\text { (deg) }\end{array}$ & $\begin{array}{c}\text { Length } \\
(\mathrm{km}) \\
\end{array}$ & $\begin{array}{c}\text { Average } \\
\text { Displacement / } \\
\text { event }(\mathrm{m})\end{array}$ & $\begin{array}{l}\text { Slip Rates } \\
\text { (mm/year) }\end{array}$ & $\begin{array}{c}\text { Last Rupture(s) } \\
\text { (years) }\end{array}$ & $\begin{array}{c}\text { Recurrence } \\
\text { Intervals }{ }^{(* *)} \\
\text { (years) } \\
\end{array}$ & $\begin{array}{l}\text { Magnitude } \\
\text { (Mw) }\end{array}$ \\
\hline \multirow[t]{9}{*}{14} & $\begin{array}{l}\text { Porters Pass - Amberley Fault } \\
\text { Zone }\end{array}$ & SS/Rev & $20-90$ & $75-85$ & $4-8$ & $3-5$ & $\begin{array}{c}500-700^{(1)} \\
2000-2500^{(1)}\end{array}$ & $1300-2000$ & \\
\hline & Mt Grey Fault & $\operatorname{Rev} / S S$ & $30-80 \mathrm{NW}$ & 15 & $2-4$ & $0.5-1.8$ & $\begin{array}{c}300-450^{(1)} \\
2300-2400^{(1)}\end{array}$ & $1300-2000$ & 6.9 \\
\hline & Mt Thomas Fault & $\mathrm{Rev} / \mathrm{SS}$ & $30-80 \mathrm{NW}$ & 16 & - & - & - & $2000-5000^{(2)}$ & 6.5 \\
\hline & Lees Valley Fault & $\mathrm{Rev} / \mathrm{SS}$ & $30-80 \mathrm{SE}$ & 25 & $1-3$ & $2.5-5.0$ & - & $(2000-5000)$ & 6.7 \\
\hline & Townshend Fault & SS/Rev & $40-90 S$ & $14-16$ & - & - & - & - & \\
\hline & Glentui Fault & SS & $60-90$ & $10-12$ & - & - & - & - & \\
\hline & Coopers Creek Fault & SS/Rev & $60-90 \mathrm{~N}$ & $14-16$ & - & - & $2000-2500$ & - & \\
\hline & Porters Pass Fault & SS & $60-90 \mathrm{~N}$ & $35-40$ & $3-8$ & $2.7-5.0$ & $\begin{array}{c}500-700^{(1)} \\
2000-2500^{(1)}\end{array}$ & - & \\
\hline & Ashley Fault/Cust Fault & $\operatorname{Rev}$ & $20-50 \mathrm{NW}$ & 72 & $0.5-4.0$ & - & - & 2000 & 7.2 \\
\hline 15 & Torlesse Fault & $\operatorname{Rev}$ & $50-80 \mathrm{SE}$ & 31 & - & - & - & $2000-4000$ & 6.7 \\
\hline \multirow[t]{2}{*}{16} & Cheeseman Fault Zone & $\operatorname{Rev}$ & $20-70 W$ & 23 & - & $0.25-1.0$ & - & $2000-5000$ & 7.0 \\
\hline & Springbank Fault & Rev & $20-70 \mathrm{NW}$ & 68 & & & & 5000 & 7.1 \\
\hline
\end{tabular}

Footnotes: $\left(^{*}\right)$ : For location of faults and index to fault numbers refer to Figure 3.

(\#) : Fault type abbreviations: ss - strike-slip; rev - reverse/thrust; $\mathrm{n}$ - normal. $\left({ }^{* *}\right)$ : Based on paleoseismic and/or slip rate data.

(') : $\mathrm{C}^{14}$ dates expressed as years B.P. are given prior to 1950 , and are only approximate to calendar years. The relationship is not constant through time. $\left({ }^{2}\right)$ : Based on recurrence interval of neighbouring faults. 
with a Holocene slip rate of $3-5 \mathrm{~mm} / \mathrm{year}$ if each displacement is 4-8 m. Cowan et al. (1996) also noted the historical seismicity for this fault zone is characterised by frequent small and moderate magnitude earthquakes and a seismicity rate that is similar to, or higher than, the region surrounding the Hope fault to the north. This is despite an order of magnitude difference in both slip rate and recurrence intervals between these respective fault zones.

Domain 4 - North Canterbury Fold and Thrust Belt: This domain includes the coastal hills southwest from Kaikoura, where NE trending thrust faults extend through the NE part of the onshore Canterbury region, and offshore across the continental shelf and slope (Figures 3 and 4 ). The thrusts are evolving in response to oblique plate convergence and the transition from subduction related tectonics in the north, to oblique continent-continent collision west of the Chatham Rise (Reyners and Cowan 1993). Thrust faults are typically associated with strongly asymmetric folds involving Mesozoic greywacke basement and Tertiary and Quaternary cover rocks, and are well expressed as topographic ridges separated by fault related synclinal valleys floored by Tertiary formations and Quaternary alluvium. These NE striking thrusts extend to within $5 \mathrm{~km}$ of the Hope fault, implying that major strike-slip faulting is mainly restricted to the Hope fault zone, and upper crustal strain partitioning is complex. Further south the east dipping thrusts extend west to the foot of the main ranges, along the west margin of the Canterbury Plains and south end of Culverden Basin.

The geologic structure of the upper crust is dominated by northeast striking imbricate reverse/thrust faults that generally dip to the northwest north from about Cheviot, and to the southeast south from there. Faults are closely associated with fault propagated asymmetric growth folds (Yousif 1987; Nicol et al. 1994; Litchfield 1995). The faults and folds are in general clearly reflected in the topography of the north Canterbury area, and geomorphic evolution is clearly driven by the active earth deformation. This region has accommodated $\sim 12-15 \%$ NW-SE shortening during the Pleistocene, and rates of shortening close to the Pacific coast are about 1\% per 100,000 years (Nicol et al. 1994; Cowan et al. 1996). Detailed studies in the southern half of this domain, along the edge of the plate boundary zone in north Canterbury, indicate that deformation probably commenced within the last 0.5-1.0 Myr (Cowan 1992; Nicol 1991; Mould 1992; Litchfield 1995; Nicol et al. 1994; Barnes 1996).

The fold and thrust belt of Domain 4 extends up to $20 \mathrm{~km}$ offshore, with structures generally trending parallel to those onland, and of similar style but with smaller amplitude (Barnes 1993; 1996). Barnes integrated high resolution seismic reflection profiles and a detailed Quaternary sequence stratigraphy to map and characterise the earthquake potential of the actively growing thrust propagated folds offshore likely to pose a seismic hazard to Christchurch and other coastal towns in north Canterbury. Eleven large-scale folds are expressed within the upper few hundred metres of a Pliocene to Holocene succession beneath the continental shelf, representing the upper part of a sedimentary cover up to $2 \mathrm{~km}$ thick. The folds are gentle, NE-SW trending, overlapping, asymmetric structures approximately $10-32 \mathrm{~km}$ in length, which verge consistently to the northwest. The folds are inferred to overlie a system of southeast dipping blind thrust faults that are accommodating a small component of regional NW-SE shortening in this structural domain. These folds are interpreted to develop by coseismic uplift during thrust-slip earthquakes.

Deposition, folding, and coastal uplift have occurred contemporaneously throughout the last 0.75 million years. Fold amplitude growth rates of $0.02 \mathrm{~m} / \mathrm{kyr}$ to $0.14 \mathrm{~m} / \mathrm{kyr}$ near the outer shelf deformation front are low, and up to 25 times lower than some actively growing folds exposing basement rocks onshore (e.g. Nicol et al. 1994). There is a significant decline in strain rate across the coastal zone and inner continental shelf, toward the offshore outer deformation front. It is inferred that blind thrust faults beneath the offshore folds have slip rates typically of the order of 0.1-0.9 $\mathrm{mm} /$ year, and that the probable recurrence interval of moderately large magnitude (M6.8-7.2) thrust earthquakes beneath individual folds is of the order of several tens of thousands of years (Barnes 1996).

The Pegasus Bay fault is the southernmost of the offshore structures, and is traced to within $5 \mathrm{~km}$ of the coast, and at its closest known point approaches to within $20 \mathrm{~km}$ of Christchurch. Barnes (1996) notes that this $\sim 30 \mathrm{~km}$ long fault-fold structure appears to diminish in amplitude as it nears the coast north of the Waimakariri River mouth, and is projected to die out. Seismic reflection data indicates that there has been no Holocene displacement across the Pegasus Bay fault. A second similar structure north of the Pegasus Bay fault affects both late Pleistocene and Holocene sediments immediately offshore from the Ashley River mouth and beyond out into the bay. However, neither structure shows evidence of movement during the last 6500 years (Barnes 1993). Based on the assumption that the growth rates of active folds may in turn be related to earthquake rupture on hidden faults at depth, Barnes (1996) has estimated earthquake recurrence intervals to range from thousands to several tens of thousands of years.

While our understanding of the geological structure and associated neotectonic processes in Structural Domain 4 are adequate, there remains very little quantitative information available in terms of long-term slip rates, and paleoseismic histories of the major earthquake source structures. Based on structural considerations it is inferred that earth deformation patterns associated with coseismic rupture on one of the major faults at depth may be widespread and complex. This will be especially the case where active faults have not ruptured fully through to the ground surface, and therefore remain "blind", and deformation is expressed by folding, warping, or tilting.

We infer a minimum of seven major seismogenic source structures onshore in this domain, including the Lowry Peaks Fault Zone (3 segments), Kaiwara fault, Omihi fault, Hundalee fault, and the Hawkeswood Range structure. Holocene rupture traces and/or surface deformation are associated with at least three of the source structures.

In summary, to date little paleoseismic information is available for this structural domain. Available data for several of the major active fault zones, as well as earthquake source parameters for the major faults located in Domain 4 are summarised in Table 4

Domain 5 - Mt Hutt-Mt Peel Fault Zone: The Southern 
Table 4: Earthquake Source Parameters for Domain 4

\begin{tabular}{|c|c|c|c|c|c|c|c|c|c|}
\hline $\begin{array}{c}\text { Fault } \\
\text { Number } \\
\left(^{*}\right)\end{array}$ & Fault Name & Fault Type $^{(*)}$ & $\begin{array}{l}\text { Interpreted } \\
\text { Dip Angle } \\
\text { (deg) }\end{array}$ & $\begin{array}{c}\text { Length } \\
(\mathrm{km})\end{array}$ & $\begin{array}{c}\text { Average } \\
\text { Displacement } \\
\text { (m) }\end{array}$ & $\begin{array}{l}\text { Slip Rates } \\
\text { (mm/year) }\end{array}$ & $\begin{array}{c}\text { Last Rupture(s) } \\
\text { (years) }\end{array}$ & $\begin{array}{c}\text { Recurrence } \\
\text { Intervals }{ }^{(* *)} \\
\text { (years) } \\
\end{array}$ & $\begin{array}{l}\text { Magnitude } \\
\text { (Mw) }\end{array}$ \\
\hline 17 & Hundalee Fault & Rev & $40-70 \mathrm{~W}$ & 41 & $1-2$ & $0.4-1.5$ & $<10,000^{(2)}$ & $800-5000$ & 7.0 \\
\hline \multirow[t]{4}{*}{18} & Lowry Peaks Fault Zone & $\operatorname{Rev}$ & $40-70 \mathrm{E}$ & 72 & $1-4$ & $1-2$ & $>10,000^{(2)}$ & & 7.3 \\
\hline & Lowry Peaks Fault & Rev & $40-70 \mathrm{E}$ & $30-35$ & - & - & $>10,000^{(2)}$ & - & \\
\hline & Leonard Mound Fault & Rev & $20-50 \mathrm{E}$ & $22-24$ & $1-4$ & - & $<10,000^{(2)}$ & - & \\
\hline & Hurunui Bluff Fault & Rev & $40-70 \mathrm{SE}$ & $18-20$ & - & - & $<10,000^{(2)}$ & - & \\
\hline 19 & Kaiwara Fault & Rev & $40-70$ & 70 & - & 0.5 & $<10,000^{(2)}$ & $2000-5000$ & 7.1 \\
\hline 20 & Omihi Fault & Rev & $40-70 \mathrm{SE}$ & 26 & - & 1 & $<10,000^{(2)}$ & - & 6.7 \\
\hline \multirow[t]{3}{*}{21} & Pegasus Bay Fault 1 & Rev & $40-70 \mathrm{SE}$ & 44 & 3 & - & $>10,000^{(2)}$ & - & 7.2 \\
\hline & Pegasus Bay Fault 2 & Rev & $40-70 \mathrm{SE}$ & 20 & 3 & - & $>10,000^{(3)}$ & - & 7.0 \\
\hline & Pegasus Bay Fault 3 & $\operatorname{Rev}$ & $40-70 \mathrm{SE}$ & 32 & 3 & - & $>10,000^{(2)}$ & - & 7.0 \\
\hline
\end{tabular}

Footnotes: $\quad\left(^{*}\right)$ : For location of faults and index to fault numbers refer to Figure 3.

$(* *)$ : Based on paleoseismic and/or slip rate data

(\#) : Fault type abbreviations: ss - strike-slip; rev - reverse/thrust; $\mathrm{n}$ - normal

(1) : $\mathrm{C}^{14}$ dates expressed as years B.P. are given prior to 1950 , and are only

$\left({ }^{2}\right)$ : relative chronology only

approximate to calendar years. The relationship is not constant through time.

$\left({ }^{3}\right)$ : Based on data from neighbouring fault. 
Alps eastern foothills rangefront south from Mt Hutt to Mt Peel is controlled by a complex array of thrust faults, folds and associated warping along the west margin of the Canterbury Plains, and is here defined as Domain 5 (Figures 3 and 4).

While Gair (1967) and Oliver and Keene (1989) document the existence of two short fault rupture traces displacing the last glacial aggradation surfaces adjacent to the Rangitata River, the wider extent of this active fault zone has only recently been discovered, and detailed mapping of the area from Mt Hutt to Winterslow Range was recently completed by (Elvy 1999). Further reconnaissance mapping by Barrell et al. (1996), and by Pettinga et al. (1998), have been completed for the rangefront from Mt Winterslow to the Mt Peel/Orari River area. These preliminary and ongoing studies have identified a late Quaternary active rangefront fault system, and this is informally named the Mt Hutt-Mt Peel Fault Zone.

Mapping to date has delineated a zone of active earth deformation, expressed by several active fault traces and broad flexures affecting last glacial and post-glacial surfaces near to, but east of the rangefront from northeast of $\mathrm{Mt}$ Alford to south of Peel Forest. The surface expression of the fault zone is complex, with discontinuous sharp fault traces and more commonly broad flexures. The latter are inferred to be the expression of faulting at depth beneath a thick cover of alluvial deposits (Barrell et al. 1996). The geometry of the deformation indicates that the faulting is contractional, driven by reverse/thrust faulting, west side being upthrown. Late last glacial surfaces are offset by up to $10 \pm 5 \mathrm{~m}$, with evidence for multiple fault rupturing events. Holocene displacements are recorded by offset younger degradational terrace surfaces south of the south branch of the Asburton River. There is no mapped evidence of lateral displacement (Barrell et al. 1996; Elvy 1999).

No historic earthquake ruptures have occurred along the Mt Hutt-Mt Peel Fault Zone. Elvy (1999) has completed paleoseismic investigations at several localities along the rangefront fault zone between the north branch of the Ashburton River and Mt Hutt. Results failed to date any single paleoseismic events, but did support significant Holocene activity on the faults investigated. No other paleoseismic studies have been undertaken along the rangefront fault zone to date. The complex nature of the surface expression of this fault zone and the limited detailed field investigations so far, precludes further comment on the possibility of seismic source fault zone segmentation models. Earthquake source parameters for the Mt Hutt-Mt Peel Fault Zone (Domain 5) are summarised in Table 5

Domain 6 - South Canterbury Zone: This Domain defines the extreme "feather-edge" margin of the Southern Alps double-sided wedge style of thrust deformation in south Canterbury, east of the MacKenzie Basin, and south of the Rangitata River.

Selected faults have been paleoseismically investigated, however, no systematic mapping of active tectonic structures has been undertaken in the south Canterbury region. The most recent regional geological mapping is that published by Gair (1967) and Mutch (1963). Oliver and Keene (1990) mapped the Lake Clearwater to Lake Heron area. Although this area lies north of the Rangitata River, is included here because the Lake Heron fault is projected to connect with other active structures south of the Rangitata River.

A significant number of northerly and northwesterly trending active faults have been identified inland from Timaru and Waimate. These include, for example, the Dryburgh, Wharekuri, Waitangi and Kirkliston faults in south Canterbury, and the Ostler fault (see following section). The activity of these faults has been the focus of investigation by the Institute of Geological and Nuclear Sciences (Table 6).

Of the twelve major seismogenic sources recognised in Domain 6 all are reverse to reverse-oblique in nature, while two are documented with a component of lateral slip. Only two have confirmed Holocene rupture activity, and from the paleoseismic work completed fault slip rates are generally low, at $<2 \mathrm{~mm} /$ year. Average single event displacements are 1-6 metres, and derived recurrence intervals are long, generally of the order of several thousand years or more. The domain reflects the progressive decrease in seismic activity southeast across the Canterbury region. Earthquake source parameters and available paleoseismic data for the major faults located in Domain 6 are summarised in Table 6 .

Domain 7 - Canterbury Plains Zone: Active earth deformation beneath the Quaternary alluvium of the Canterbury Plains is indicated by earthquake activity. This represents a significant source area of hidden, but as yet unstudied earthquakes in the region, and is here included as a separate domain.

The Canterbury Plains are comprised of a series of large coalescing alluvial fans covering about $8,000 \mathrm{~km}^{2}$ between the eastern foothills of the Southern Alps and the Pacific Ocean. The thick succession of Quaternary alluvial fan gravels have been deposited by the major rivers draining the Southern Alps, including the Waimakariri, Rakaia, Ashburton, and Rangitata.

Instrumentally recorded seismicity beneath the Canterbury Plains indicates the area is subject to some neotectonic activity. However, with the exception of the northwest Canterbury plains, no active fault or fold structures are geomorphically expressed at the surface away from the rangefront, or the immediate foreland area of the rangefront. In this context it is important to note that the highest recorded levels of ground shaking (intensity MM7-8) in Christchurch city were recorded in 1869 during the Christchurch Earthquake (Stirling et al. 1999) - previously referred to as the New Brighton Earthquake by Dibble et al. (1980) and Elder et al. (1991). Based on a detailed review of available historic accounts these authors inferred an epicentral location close to Christchurch.

Very limited and generally poor quality seismic reflection data are available for the Canterbury Plains (Kirkaldy and Thomas 1963). In addition, regional gravity surveys (Hicks 1989) indicate considerable subsurface structural complexity. The significance of instrumentally recorded seismicity with respect to "hidden" earthquake source structures cannot be further assessed at this time, and there is a need for more detailed study of the earthquake source potential of this region.

In contrast to the north Canterbury region of Domain 4 , there 
Table 5: Earthquake Source Parameters for Domain 5

\begin{tabular}{|c|c|c|c|c|c|c|c|c|c|}
\hline $\begin{array}{c}\text { Fault } \\
\text { Number } \\
\left({ }^{*}\right)\end{array}$ & Fault Name & $\begin{array}{c}\text { Fault } \\
\text { Type }^{(t)}\end{array}$ & $\begin{array}{c}\text { Interpreted } \\
\text { Dip Angle } \\
\text { (deg) }\end{array}$ & $\begin{array}{l}\text { Length } \\
(\mathrm{km})\end{array}$ & $\begin{array}{c}\text { Average } \\
\text { Displacement (m) }\end{array}$ & $\begin{array}{l}\text { Slip Rates } \\
\text { (mm/year) }\end{array}$ & $\begin{array}{c}\text { Last } \\
\text { Rupture(s) } \\
\text { (years) }\end{array}$ & $\begin{array}{c}\text { Recurrence } \\
\text { Intervals }^{(* *)} \\
\text { (years) }\end{array}$ & $\begin{array}{l}\text { Magnitude } \\
\text { (Mw) }\end{array}$ \\
\hline 22 & Mt Hutt - Mt Peel Fault Zone & Rev & $40-70 W$ & 64 & $2-4$ & $0.5-1.5$ & $<10,000^{(1)}$ & $5-10,000$ & 7.3 \\
\hline
\end{tabular}

Footnotes: $\left({ }^{*}\right)$ : For location of faults and index to fault numbers refer to Figure 3 .

$\left({ }^{* *}\right)$ : Based on paleoseismic and/or slip rate data.

(\#) : Fault type abbreviations: ss - strike-slip; rev - reverse/thrust; $\mathrm{n}$ - normal.

(1) : relative chronology only 
Table 6: Earthquake Source Parameters for Domain 6

\begin{tabular}{|c|c|c|c|c|c|c|c|c|c|}
\hline $\begin{array}{c}\text { Fault } \\
\text { Number } \\
\left(^{*}\right)\end{array}$ & Fault Name & $\begin{array}{c}\text { Fault } \\
\text { Type }^{(*)}\end{array}$ & $\begin{array}{c}\text { Interpreted } \\
\text { Dip Angle } \\
\text { (deg) }\end{array}$ & $\begin{array}{l}\text { Length } \\
(\mathrm{km}) \\
\end{array}$ & $\begin{array}{c}\text { Average } \\
\text { Displacement } \\
(\mathrm{m}) \\
\end{array}$ & $\begin{array}{l}\text { Slip Rates } \\
\text { (mm/year) }\end{array}$ & $\begin{array}{c}\text { Last Rupture(s) } \\
\text { (years) }\end{array}$ & $\begin{array}{c}\text { Recurrence } \\
\text { Intervals }^{\left({ }^{* *}\right)} \\
\text { (years) }\end{array}$ & $\begin{array}{l}\text { Magnitude } \\
(\mathrm{Mw})\end{array}$ \\
\hline \multirow[t]{3}{*}{23} & Hunters Hills Fault Zone & Rev & $40-70 W$ & 62 & $3-6(?)$ & $0.5-1.0$ & $>10,000^{(2)}$ & - & \\
\hline & Northern Segment & $\operatorname{Rev}$ & $40-70 W$ & 27 & $3-6(?)$ & $0.5-1.0$ & $>10,000^{(2)}$ & - & 7.2 \\
\hline & Southern Segment & Rev & $40-70 W$ & 35 & $3-6(?)$ & $0.5-1.0$ & $>10,000^{(2)}$ & - & 7.2 \\
\hline 25 & $\begin{array}{l}\text { Fox Peak-Fairlie } \\
\text { Fault Zone }\end{array}$ & Rev & $40-70 W$ & 35 & $3-5$ & $\sim 1.0$ & $<10,000^{(2)}$ & $2,500-18,000$ & 7.2 \\
\hline 26 & Lake Heron Fault & $\operatorname{Rev}$ & $25-60 W$ & 36 & $3-5$ & $\sim 1.0$ & $<10,000^{(2)}$ & $2,500-7,500$ & 7.3 \\
\hline \multirow[t]{8}{*}{27} & Dryburgh Fault SE & $\operatorname{Rev}$ & $40-70 \mathrm{SW}$ & 20 & $1-4(?)$ & $0.01-0.15$ & $>10,000^{(2)}$ & - & 6.9 \\
\hline & Dryburgh Fault NW & Rev & $40-70 \mathrm{SW}$ & 24 & $1-4(?)$ & $0.01-0.15$ & $>10,000^{(2)}$ & - & 6.9 \\
\hline & Waitangi Fault & Rev & $50-70$ & 18 & $0.5-2.5$ & $0.01-0.15$ & $<20,000^{(2)}$ & - & 6.5 \\
\hline & Wharekuri Fault & $\begin{array}{l}\text { Rev/SS } \\
\text { sinistral }\end{array}$ & $40-70$ & 44 & $2-6$ & $0.1-0.6$ & $<20,000^{(2)}$ & - & 7.2 \\
\hline & Kirkliston Fault & Rev & $40-70 \mathrm{NW}$ & 35 & $1-5(?)$ & $0.02-0.1$ & - & - & 7.1 \\
\hline & Otematatapaio Fault & Rev/SS & $60-90 \mathrm{SW}$ & 16 & 0.8 & $0.01-0.03(0.01)$ & & - & 6.4 \\
\hline & Dalgety Fault & $\operatorname{Rev}$ & $\sim 60$ & 26 & $1 \cdot 5$ & $0.02-0.1$ & & - & 7.0 \\
\hline & Rostriever/Big Gully Fault & $\operatorname{Rev}$ & 90 & 11 & $1-4$ & $\sim 0.05$ & & - & 6.7 \\
\hline
\end{tabular}

Footnotes: $\quad\left(^{*}\right)$ : For location of faults and index to fault numbers refer to Figure 3. $\left(^{* *}\right)$ : Based on paleoseismic and/or slip rate data.
(\#) : Fault type abbreviations: ss - strike-slip; rev - reverse/thrust; $\mathrm{n}$ - normal. (') : $\mathrm{C}^{14}$ dates expressed as years B.P. are given prior to 1950 , and are only approximate to calendar years. The relationship is not constant through time. $\left({ }^{2}\right)$ : Relative chronology only 
is little evidence for neotectonic deformation affecting the continental shelf, offshore of south Canterbury. All tectonic structures recognised in seismic profiles appear to be inactive during the Late Quaternary, with the exception of one fault, located near the outer edge of the continental shelf. Browne (pers comm. 1997) reports that an active fault displacing Late Pleistocene sediments is present about $30 \mathrm{~km}$ offshore from Timaru. To date this has not been studied in detail.

Domain 8 - Southern Alps Zone: This domain extends east from the main divide and includes the Ostler Fault Zone (Van Dissen et al. 1993) and the Main Divide Fault Zone (Cox and Findlay 1995). Deformation is dominated by oblique reverse/thrust faulting, inferred to represent back-thrusting off the dipping Alpine fault, and is considered of fundamental importance in terms of uplift and strain within the Southern Alps.

The Southern Alps Structural Domain lies adjacent to, and in part includes the high strain zone associated with the eastern upthrown side of the Alpine fault. While considerable work is currently in progress on the Alpine fault itself, the rugged mountainous terrain of the Southern Alps has been little studied in terms of active earth deformation, in part because of the high erosion rates and consequent lack of preserved active tectonic features. In recent years new data on the seismicity, geodetic strain monitoring, uplift rates, and structural analysis have shed considerable insights into the neotectonic processes operating to form the Southern Alps. However, with the exception of the Alpine fault itself, identification of active faults, coseismic deformation rates, and paleoseismic data for Southern Alps structures remains sparse.

The eastern margin to this structural domain is well defined by several mapped active fault zones, including the Ostler Fault Zone and the Irishman Creek Fault Zone. However, our understanding of the distribution and size of large earthquake sources in Domain 8 is still limited. While several major seismogenic sources are documented, for much of the area little data is available on the pre-historic large earthquake activity. Given the terrain constraints it is probable that conventional paleoseismic mapping techniques are unlikely to prove successful in gaining a significantly better understanding of earthquake sources in this Domain. Earthquake source parameters and available paleoseismic data for the major faults located in Domain 8 are summarised in Table 7.

\section{MAJOR EARTHQUAKE SOURCES OUTSIDE OF THE CANTERBURY REGION}

In order to undertake a comprehensive probabilistic seismic hazard assessment for the Canterbury region it is essential that large earthquake sources outside of, but situated near to, the Canterbury region are also identified and characterised in terms of fault type, geometry and activity. Important sources are located on Figure 3, and available data summarised in Table 8. However, in the following section the most important of these external sources, the Alpine fault, is reviewed in more detail, and is included as Structural Domain 9 (Figures 3 and 4). This is done primarily because it is considered capable of generating a great earthquake (>Magnitude 8), and this is likely to impact the entire Canterbury region. In addition, a significant new body of paleoseismic data is now available for the Alpine fault, allowing for a more comprehensive probabilistic hazard assessment (see Stirling et al. this volume).

Domain 9 - Alpine Fault Zone: The Alpine fault, and its northward continuation as the Wairau fault from near Lake Rotoiti, is the longest active fault in the South Island extending $650 \mathrm{~km}$ from offshore south of Milford Sound to near Blenheim (Berryman et al. 1992) (Figure 3). It is the western range bounding fault of the Southern Alps with the maximum rates of uplift in the central section, between the Haast River and the Taramakau River, estimated at $\sim 7-10$ $\mathrm{mm} / \mathrm{yr}$ (Bull and Cooper 1989; Simpson et al. 1994; Yetton 2000; Norris and Cooper 2001). The Southern Alps are forming in response to the shortening component of plate motion which is oblique to fault strike. However, the dominant component of fault movement is dextral shear with average horizontal slip rates estimated at $27 \pm 5 \mathrm{~mm} / \mathrm{yr}$ (Norris and Cooper 1997; 2001), and average single event displacements ranging from about 4-8 metres (Berryman et al. 1998; Yetton et al. 1998).

Berryman et al. (1992) divided the fault into four sections (Wairau; north Westland; central Westland; south Westland). These sections were defined on the basis of geomorphology and structural style. Berryman et al. also suggested these sections may represent fault rupture segments, but noted a lack of data in support of this inference. Bull (1996) also inferred rupture segment boundaries, the first at the Taramakau River, and the second at the "big bend" of the Alpine fault in northern South Island.

Although the fault daylights west of the Canterbury region, based on geological and geophysical evidence the fault dips east beneath western Canterbury at seismogenic depths (Norris et al. 1990; Pettinga and Wise 1994; Davey et al. 1995; Kleffman et al. 1998), and thus has an inferred epicentral region which extends beneath the west Canterbury region. The importance of the Alpine fault as a potential seismic source in seismic hazard analysis for the South Island has previously been recognised (e.g. Adams 1980; Smith and Berryman 1983, 1986; Elder et al. 1991). However, until recently there has only been limited paleoseismic data available.

There has been no historical surface rupture on the Alpine fault, and the traditional view has been that levels of recorded crustal seismicity since 1944 are relatively low. This led to the term "seismic gap" (e.g. Adams 1980) to describe the pattern of shallow seismicity in the region of the central Westland section of the fault. Recent improvements in the seismograph network indicate more seismicity is occurring than was being recorded in the old network (EberhartPhillips, 1995). Seismicity extends to a depth of about $10 \mathrm{~km}$ near the Alpine fault, to more than $20 \mathrm{~km}$ away from, and east of the fault. While levels of activity are still relatively low, it is comparable to the Mojave section of the San Andreas fault which last ruptured in 1857, and is estimated to have at least 10 large earthquakes in the last 1400 years (Sieh et al. 1989). The Alpine fault is now widely considered to be a major "locked" seismogenic source (e.g. Yetton et al. 1998; Norris 1999).

Most early assessments of paleoseismicity on the Alpine fault were based on Adams (1980). He obtained a limited number 
Table 7: Earthquake Source Parameters for Domain 8

\begin{tabular}{|c|c|c|c|c|c|c|c|c|c|}
\hline $\begin{array}{c}\text { Fault } \\
\text { Number } \\
(*)\end{array}$ & Fault Name & Fault Type $^{(t)}$ & $\begin{array}{c}\text { Interpreted } \\
\text { Dip Angle } \\
\text { (deg) }\end{array}$ & $\begin{array}{c}\text { Length } \\
(\mathrm{km}) \\
\end{array}$ & $\begin{array}{c}\text { Average } \\
\text { Displacement } \\
(\mathrm{m}) \\
\end{array}$ & $\begin{array}{l}\text { Slip Rates } \\
\text { (mm/year) } \\
\end{array}$ & $\begin{array}{c}\text { Last Rupture(s) } \\
\text { (years) }\end{array}$ & $\begin{array}{c}\text { Recurrence } \\
\text { Intervals }{ }^{(* *)} \\
\text { (years) } \\
\end{array}$ & $\begin{array}{l}\text { Magnitude } \\
\text { (Mw) }\end{array}$ \\
\hline 28 & Irishman Creek Fault Zone & $\operatorname{Rev}$ & $40-70 W$ & 25 & $2-6$ & $<0.5$ & $>10,000^{(2)}$ & 15,000 & 7.0 \\
\hline \multirow[t]{4}{*}{29} & Ostler Fault Zone & & & & & & & & \\
\hline & Northern Segment & $\mathrm{Rev} / \mathrm{SS}$ & $60-80 W$ & 24 & $2-4(?)$ & 1.0 & $2850-4410^{(1)}$ & $3000 \pm 1000$ & 7.0 \\
\hline & Central Segment & $\mathrm{Th} / \mathrm{Rev}$ & $40-70 W$ & 24 & $2-4$ & 1.0 & $>439^{(1)}$ & $3000 \pm 1000$ & 7.0 \\
\hline & Southern Segment & $\mathrm{Th} / \operatorname{Rev}$ & $40-70 W$ & 18 & $2-4$ & 1.0 & - & $3000 \pm 1000$ & 6.9 \\
\hline 30 & Main Divide Fault Zone & Rev/SS & $40-70 \mathrm{NW}$ & $50(+)$ & - & - & - & - & \\
\hline
\end{tabular}

Footnotes: $\left(^{*}\right)$ : For location of faults and index to fault numbers refer to Figure 3 . $(* *)$ : Based on paleoseismic and/or slip rate data.
(\#) : Fault type abbreviations: ss - strike-slip; rev/th - reverse/thrust; $\mathrm{n}$ - normal.

(l) : $\mathrm{C}^{14}$ dates expressed as years B.P. are given prior to 1950 , and are only

approximate to calendar years. The relationship is not constant through time.

$\left(^{2}\right)$ : Relative chronology only 
Table 8: Earthquake Source Parameters for Faults Outside the Canterbury Region, including the Alpine fault (structural domain 9).

\begin{tabular}{|c|c|c|c|c|c|c|c|c|c|}
\hline $\begin{array}{c}\text { Fault } \\
\text { Number } \\
\left({ }^{*}\right)\end{array}$ & Fault Name & Fault Type $^{(\#)}$ & $\begin{array}{c}\text { Interpreted } \\
\text { Dip Angle } \\
\text { (deg) } \\
\end{array}$ & $\begin{array}{r}\text { Length } \\
(\mathrm{km}) \\
\end{array}$ & $\begin{array}{c}\text { Average } \\
\text { Displacement } \\
(\mathbf{m}) \\
\end{array}$ & $\begin{array}{l}\text { Slip Rates } \\
\text { (mm/year) } \\
\end{array}$ & $\begin{array}{c}\text { Last Rupture(s) } \\
\text { (years) }\end{array}$ & $\begin{array}{c}\text { Recurrence } \\
\text { Intervals }^{(* *)} \\
(\text { years }) \\
\end{array}$ & $\begin{array}{c}\text { Magnitude } \\
(\mathrm{Mw})\end{array}$ \\
\hline 31 & Waimea Fault & $\operatorname{Rev} / S S$ & 90 & 69 & & $0.5-2.0$ & - & & 7.0 \\
\hline 32 & White Creek Fault & $\operatorname{Rev}$ & 70 & 40 & 6 & 0.2 & - & 34,000 & 7.6 \\
\hline 33 & Lyell Fault & $\operatorname{Rev} / \mathrm{SS}$ & 90 & 29 & & 0.2 & - & & 6.7 \\
\hline \multirow[t]{2}{*}{34} & Brunner Anticline & $\operatorname{Rev}$ & 90 & 52 & & $0.28-0.47$ & - & 15,000 & 6.9 \\
\hline & Paparoa Range Front F. & $\operatorname{Rev}$ & & 77 & & & - & 5,000 & 7.1 \\
\hline 35 & Inangahua Fault & $\operatorname{Rev}$ & $45 \mathrm{SE}$ & 16 & 0.4 & 0.1 & - & 4,400 & 7.4 \\
\hline 36 & Kelly Fault & SS & 90 & 48 & & & - & 650 & 6.9 \\
\hline 37 & Pisa Fault & Rev & $55 \mathrm{NW}$ & 39 & 3.0 & 0.37 & - & 30,000 & 7.1 \\
\hline 38 & Nevis Fault & $\operatorname{Rev}$ & $55 \mathrm{NW}$ & 34 & & 0.3 & - & & 6.8 \\
\hline 39 & Ahuriri River Fault & Rev & 90 & 15 & 2.5 & & - & 10,000 & 6.8 \\
\hline 40 & Quartz Creek Fault & $\operatorname{Rev}$ & $75 \mathrm{SW}$ & 12 & $1-4(2.5)$ & & - & 5,000 & 6.7 \\
\hline 41 & Lindis Pass Fault & $\operatorname{Rev} / \mathrm{SS}$ & 90 & 28 & 3.0 & - & - & 3,000 & 7.0 \\
\hline 42 & Grandview Fault & $\operatorname{Rev}$ & 90 & 25 & 3.0 & - & - & 30,000 & 7.0 \\
\hline 43 & Cardrona South Fault & Rev & $30 \mathrm{NW}$ & 30 & 2.0 & 0.25 & - & 7,500 & 7.1 \\
\hline 44 & Cardrona North Fault & $\operatorname{Rev} / \mathrm{SS}$ & $30 \mathrm{NW}$ & 25 & 2.0 & 0.25 & - & 7,500 & 7.0 \\
\hline 45 & Blue Lake Fault & $\operatorname{Rev}$ & $60 \mathrm{NE}$ & 24 & 3.0 & - & - & 5,000 & 7.0 \\
\hline 46 & Dunstan North Fault & $\operatorname{Rev}$ & $60 \mathrm{NW}$ & 38 & 4.0 & $0.5-1.0$ & - & 8,000 & 7.2 \\
\hline 47 & Dunstan South Fault & Rev & $60 \mathrm{NW}$ & 16 & 4.0 & $0.5-1.0$ & - & 8,000 & 7.0 \\
\hline 48 & Raggedy Fault & Rev & $60 \mathrm{NW}$ & 24 & 3.0 & - & - & 8,000 & 7.0 \\
\hline 49 & North Rough Ridge F. & Rev & $60 \mathrm{NW}$ & 24 & 3.0 & - & - & 8,000 & 7.0 \\
\hline 50 & Rough Ridge Fault & $\operatorname{Rev}$ & $60 \mathrm{NW}$ & 23 & 3.0 & - & - & 8,000 & 7.0 \\
\hline 51 & Ranfurly South Fault & $\operatorname{Rev}$ & $60 \mathrm{NW}$ & 22 & 3.0 & - & - & 8,000 & 7.0 \\
\hline 52 & Ranfurly North Fault & $\operatorname{Rev}$ & $60 \mathrm{NW}$ & 21 & 3.0 & - & - & 8,000 & 7.0 \\
\hline 53 & Hyde Fault & $\operatorname{Rev}$ & $60 \mathrm{NW}$ & 28 & 3.0 & - & - & 15,000 & 7.0 \\
\hline
\end{tabular}


Table 8

\begin{tabular}{|c|c|c|c|c|c|c|c|c|c|}
\hline $\begin{array}{c}\text { Fault } \\
\text { Number } \\
(*)\end{array}$ & Fault Name & Fault Type & $\begin{array}{c}\text { Interpreted } \\
\text { Dip Angle } \\
\text { (deg) }\end{array}$ & $\begin{array}{c}\text { Length } \\
(\mathbf{k m}) \\
\end{array}$ & $\begin{array}{c}\text { Average } \\
\text { Displacement } \\
(\mathbf{m}) \\
\end{array}$ & $\begin{array}{l}\text { Slip Rates } \\
(\mathrm{mm} / \text { year }) \\
\end{array}$ & $\begin{array}{c}\text { Last Rupture(s) } \\
\text { (years) }\end{array}$ & $\begin{array}{c}\text { Recurrence } \\
\text { Intervals }^{(* *)} \\
\text { (years) } \\
\end{array}$ & $\begin{array}{l}\text { Magnitude } \\
\text { (Mw) }\end{array}$ \\
\hline \multirow[t]{4}{*}{54} & Avoca Fault & SS & 90 & 19 & - & - & - & 3,500 & 6.7 \\
\hline & Wairarapa Fault & SS/Rev & 90 & 111 & 12.1 & $3.1-15.8$ & & 2,000 & 8.1 \\
\hline & $\begin{array}{l}\text { Hikurangi Subduction } \\
\text { (Hawkes Bay Segment) }\end{array}$ & - & $15 \mathrm{~W}$ & 156 & - & 10.0 & - & - & 8.2 \\
\hline & $\begin{array}{l}\text { Hikurangi Subduction } \\
\text { (Wellington Segment) }\end{array}$ & - & $15 \mathrm{~W}$ & 192 & - & 15.0 & - & - & 8.3 \\
\hline \multirow[t]{3}{*}{1} & Alpine Fault & & & & & & & & \\
\hline & Milford-Haupiri Segment & SS/Rev & $60-90 \mathrm{SE}$ & 380 & 8 & $15-35(25)$ & $\begin{array}{l}1717^{(1)} ; \pm 1620^{(1)} \\
\quad \pm 1425^{(1)}\end{array}$ & 250 & 8.0 \\
\hline & Haupiri-Tophouse S. & $\mathrm{SS} / \mathrm{Rev}$ & $40-70 \mathrm{SE}$ & 188 & 5 & $2.4-12$ & - & 500 & 7.7 \\
\hline 55 & North Mernoo Banks - North & $\mathrm{N}$ & - & 136 & - & - & - & 1000 & 7.4 \\
\hline 56 & North Mernoo Banks - South & $\mathrm{N}$ & - & 116 & - & - & - & 1000 & 7.4 \\
\hline
\end{tabular}

Footnotes: $\quad(*)$ : For location of faults and index to fault numbers refer to Figure 3.

(\#) : Fault type abbreviations: ss - strike-slip; rev/th - reverse/thrust; $\mathrm{n}$ - normal. $(* *)$ : Based on paleoseismic data and/or slip rate.

(1) : Given as years $\mathrm{AD}$ 
of radiocarbon $\left({ }^{14} \mathrm{C}\right)$ dates from landslides and aggradation terraces in central and south Westland spanning the last 2000 years. Based on this indirect evidence he inferred Alpine fault earthquakes at approximately 500-year intervals over the last 2000 years, with the most recent event around 550 years ago. Adams acknowledged that this paleoseismic record was likely to be incomplete. Further work on paleoseismicity of the central Alpine fault includes that by Bull (1996), and Bull and Brandon (1998). These authors infer a quite different pattern of past earthquakes on the Alpine fault based on lichenometric dating of rockfalls. However, the rockfall sites used are all well east of the fault, the closest being approximately $18 \mathrm{~km}$ away and the majority more than $25 \mathrm{~km}$.

Prior to 1998 the only other significant paleoseismic investigations of the Alpine fault includes the work of Cooper and Norris (1990), near Milford Sound, and Sutherland and Norris (1995) near Lake McKerrow in South Westland. Cooper and Norris (1990) radiocarbon dated material excavated from sag ponds near the fault scarp and estimated the age of trees which appeared to have lost their crowns as a result of earthquake shaking. They concluded that the last large earthquake in the area due to movement of the Alpine fault occurred in the period between $1650 \mathrm{AD}$ and 1725 AD. Sutherland and Norris (1995) used displaced river channels to estimate the ground displacements of the last two earthquake ruptures on the Alpine fault, and provided an estimate of the timing for the last rupture at $370 \pm 150 \mathrm{cal}$. $\mathrm{yr}$ B.P.

Since 1998 a number of studies have addressed Alpine fault paleoseismicity, extending over the region from central to south Westland (Berryman et al. 1998; Yetton et al. 1998; Wright 1998; Wright et al. 1998; Yetton and Wells 1998; Wells et al. 1999; Yetton 2000). These studies form the basis of the paleoseismic information summarised here, with data obtained from the direct trenching of the fault, landslide and terrace chronologies, forest disturbance events, and disturbance to individual trees as reflected in anomalies of the tree ring growth patterns.

Data from the central Westland section of the Alpine fault, north from the Franz Josef area, indicates at least five ground rupture events over the last 1400 years (Wright et al. 1998; Yetton et al. 1998; Yetton and Wells 1998; Wells et al. 1999). Dates for three of the last four strong ground shaking events are consistent, and include $\sim 1210 \mathrm{AD} ; 1425 \pm 15 \mathrm{AD}$, and $1717 \mathrm{AD}$. However, based on tree ring patterns at the Waitaha River site, Wright (1998) and Wright et al. (1998) prefer a date for the penultimate earthquake of $1580 \pm 5 \mathrm{yr}$, as opposed to the Yetton et al. (1998) and Yetton (2000) estimate of $1620 \pm 10$ years.

Studies of the southern section of the fault, south from Haast, have yielded evidence for three ground rupturing events over the last 1000 years (Cooper and Norris 1990; Sutherland and Norris, 1995; Berryman et al. 1998). Berryman et al. (1998) carried out trenching at Haast and Okuru Rivers in south Westland. They recognised three ruptures of the fault in this area over the last 1000 years, each with around $8 \mathrm{~m}$ of strikeslip offset. Constraints on event timing are limited but they conclude their paleoseismic evidence is consistent with a date for the most recent event of $1717 \mathrm{AD}$.
The tree ring data implies simultaneous rupture along at least $375 \mathrm{~km}$ of fault strike (Wells et al. 1999). This provides a minimum estimate of earthquake magnitude based on the magnitude to rupture length regression estimates of Anderson et al. (1996) and Wells and Coppersmith (1994). These methods suggest a range of magnitude from $\mathrm{M}=7.9-8.2$.

The last earthquake rupture crossed the Alpine fault "segment" boundaries proposed by Bull (1996) and the "section" boundaries of Berryman et al. (1992). These boundaries had been tentatively proposed on geomorphic and structural grounds. While the division into geographic sections (Berryman et al. 1992) may still be useful for location description it appears there may not be persistent segmentation in the rupture sense.

To date paleoseismic information for the northern section of the Alpine fault, extending from the Ahaura River, near the junction of the Alpine and Hope faults, north to Lake Rotoiti, is sparse. Estimates for strike-slip rates range from $6 \pm 2.5$ $\mathrm{mm} / \mathrm{yr}$ (Yetton et al. 1998) to $10 \pm 2 \mathrm{~mm} / \mathrm{yr}$ (Berryman et al. 1992), and it is evident that slip is progressively partitioned off to the north, onto the main faults of the Marlborough Fault Zone.

Recurrence intervals for inferred Alpine fault events over the last 1500 years appear to vary considerably, from 100 years to more than 380 years, with an average around 250 years and a standard deviation of $\sim 96$ years. This amount of variation is not unusual for other large plate boundary faults in similar geologic settings. For example Sieh et al. (1989) in their work at Pallet Creek on the Mojave segment of the San Andreas fault, demonstrate a range in recurrence interval of 45 - 332 years about an average of $\sim 160$ years and a standard deviation of 102 years.

In summary, research to date clearly indicates that the Alpine fault is capable of generating large to great earthquakes at upper crustal depths along the western margin of the Canterbury region. An Alpine fault event will therefore form a major ground shaking hazard to the region.

\section{HISTORICAL EARTHQUAKES}

A significant contribution to our understanding of the earthquake hazard for geographically extensive regions comes from the historical record of earthquake locations and their felt effects. In this section we describe the nature and limitations of the New Zealand National Earthquake Information Database (also referred to as the Earthquake Catalogue), and describe major historical earthquakes felt strongly and/or widely within the Canterbury region up to and including 1997. The Pettinga et al. (1998) report identified three historic earthquakes (in 1869, 1870 and 1881) that, because of their proximity to, and effects upon Christchurch, required additional investigation. This work was subsequently completed as part of the Stage 1 (Part B) report to Canterbury regional Council (Stirling et al. 1999), and will form the subject of a future publication.

\section{New Zealand National Earthquake Information Database:}

The National Earthquake Information Database, maintained by the Institute of Geological \& Nuclear Sciences (IGNS), includes the locations of nearly 150,000 earthquakes. The 
historical section of the database may be divided into two sections:

Pre-instrumental (pre-1901) and early-instrumental (19011942): Important pre-instrumental earthquakes have been located and assigned a magnitude by analysing written accounts and newspaper reports of their felt effects. Written material for the Canterbury region is available from about the early 1850's, when European colonization had begun.

As instruments of the early-instrumental period (1901-1942) were mostly inadequate for locating earthquakes, the locations of events in this period also depend heavily on analyzing the distribution of their felt effects. IGNS holds only a limited amount of information on earthquakes in this period. The result is that, for the period 1855-1942, a definitive list of earthquakes has not been prepared, and the database is inhomogeneous and incomplete. Generally, only the larger magnitude events are recorded. It is, however, likely that all shallow earthquakes of magnitude 7 and greater that have occurred since the late 1840's in the Canterbury region have been recognised.

The location accuracy of the pre-instrumental and earlyinstrumental earthquakes is non-uniform, as few have been studied intensively. Many have been located only to the nearest degree or half degree of latitude and longitude. Consequently there may be up to $50 \mathrm{~km}$ uncertainty in given locations.

Instrumental (1942-1997): By the early 1940's the distribution of the seismographs of the National Network had developed sufficiently to give reasonable coverage for shallow earthquakes of magnitude $\mathrm{M}_{\mathrm{L}}>4.3$ between the latitudes $38^{\circ}$ and $42^{\circ} \mathrm{S}$, providing all stations were operating. A large part of the Canterbury region is located to the south of the reliable network of that time, and so some of the smaller earthquakes will not have been recorded widely enough to be well located. However, we believe that all $\mathrm{M}_{\mathrm{L}}>$ 6 earthquake events were reliably located from about 1943.

The New Zealand National Network of seismographs has been progressively upgraded since the 1940's such that in 1997, a network of over 70 digital stations, including several special-purpose local networks, cover the country. All shallow earthquakes of $\mathrm{M}_{\mathrm{L}} \geq 3.5$ and deep earthquakes of $\mathrm{M}_{\mathrm{L}}$ $\geq 3.8$ in New Zealand including the entire Canterbury region can now be well located.

The Database also includes the felt effects of many earthquakes measured by the MM intensity scale. The complete list of MM intensities for a particular earthquake in the period 1943-1997 can be obtained from the Database. Isoseismal maps for most of the more significant earthquakes to have occurred in the Canterbury region are available from the database, and many have been published (e.g. Downes 1995).

Method for this study: A search of the National Earthquake Information Database (1943-1997) was undertaken to obtain epicentres of shallow earthquakes (depth $\leq 40 \mathrm{~km}$ ) with magnitudes $\mathrm{M}_{\mathrm{L}} \geq 3.0$ between latitudes $41^{\circ} \mathrm{S}$ and $45.5^{\circ} \mathrm{S}$ and longitudes $169.0^{\circ} \mathrm{E}$ and $175.0^{\circ} \mathrm{E}$. These are plotted in Figure 5. Large magnitude earthquakes $\left(\mathrm{M}_{\mathrm{L}} \geq 6.0\right)$ for the period 1840-1997 within, or proximal to, the region were then identified and are shown in Figure 6. Further, earthquakes for which intensities of MM6 and above were observed or predicted to have occurred, within the region, were also obtained from the Database. Using both sets of data we identified the earthquakes that affected most significantly the Canterbury region within the whole historical period, that is, 1840-present. These earthquakes are detailed in Tables 9 and 10 , and their epicentres, along with other magnitude M 6+ events, are shown in Figure 6. Available isoseismal maps are given in Figure 7. Once the earthquakes had been selected, observatory file and historical records (where available) were searched to determine the nature of the felt effects recorded at Christchurch or any of six centres; Kaikoura, Hanmer Springs, Arthur's Pass, Mount Cook, and Twizel. The distribution of these centres should represent the seismicity experienced historically in various parts of the Canterbury region. Intensities of MM6 or more are not predicted nor have been recorded in Timaru from any earthquake in the database and hence Timaru is omitted from Table 10. Other estimates of felt intensity from unpublished work by Dibble et al. (1980), and publications by Cowan (1991) and Dowrick (1992) are also included. These contain information on mainly Christchurch and Banks Peninsula.

\section{Significant Earthquakes Felt within the Canterbury Region in Historical Times:}

1840 to 1997: Organized European settlement of Christchurch and Lyttelton began in 1853 but there were some settlers prior to this date. Hence, our database records the effects of some earthquakes between 1840 and 1853 and it is likely that earthquakes that were damaging in the eastern parts of the region have been recognised but earthquakes that caused damage in the western and southwestern parts only may have escaped recognition.

Since 1840 one $84 \mathrm{~km}$ deep and sixteen shallow (depth $\leq 40$ $\mathrm{km}$ ) earthquakes having magnitudes between 6.0 and 7.8 have occurred within or proximal to the Canterbury region, and have produced MM intensities estimated at MM6 or more in parts of the region. Figure 6 shows the locations of all magnitude 6.0 and above earthquakes within the region. It also shows the epicentres of other earthquakes outside the region that have caused widespread intensities of MM6 or more within the region. For example a magnitude M8.1-8.2 earthquake on the Wairarapa fault in 1855, although some distance from the Canterbury region, produced intensities of MM6 and MM7 in the region's northern parts. The most significant of the events shown in Figure 6 to have impacted the Canterbury region over the last 150 years are detailed in the Appendix to this paper.

Other earthquakes have caused intensities of MM6 or more, but their effects were of limited areal extent and generally in sparsely populated areas. These events include most of the magnitude M 6+ events plotted in Figure 6, and some other events, in particular near Hanmer Springs and Arthur's Pass, with magnitudes between 5.0 and 6.0. The Appendix presents a brief summary of the major earthquakes. 
Table 9: Significant earthquakes for the Canterbury region and felt intensities at six centres within the Canterbury Region in historical time (1840-1997). Data from the NZ Earthquake Information Database.

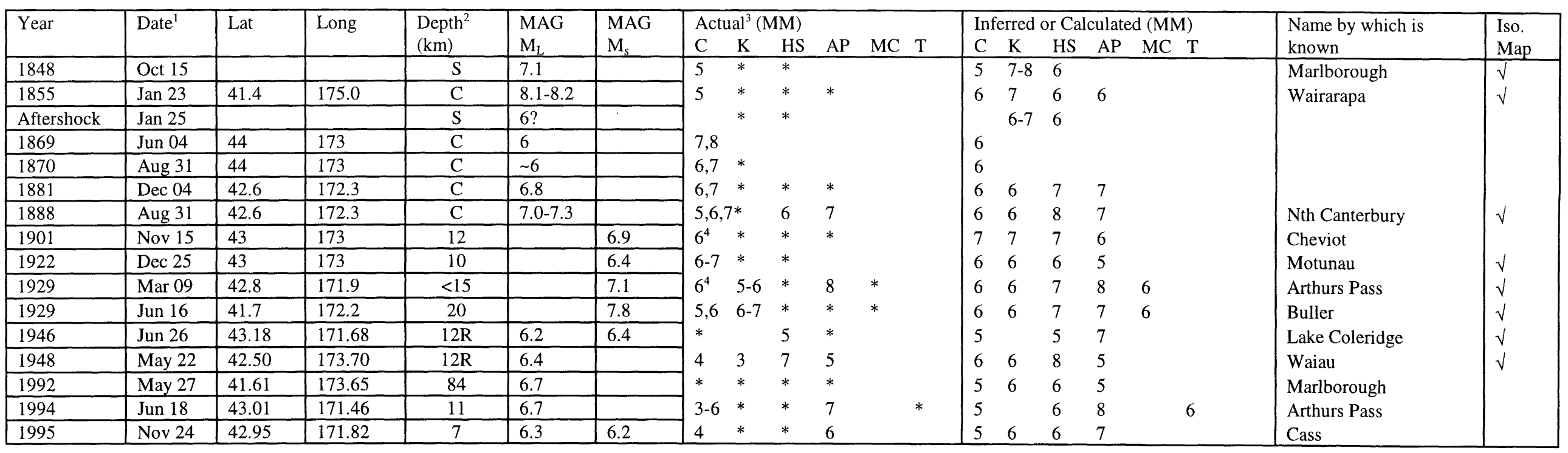

\section{NOTES:}

Date and time are based on Universal Time.

$\mathrm{C}=$ Christchurch $\quad \mathrm{AP}=$ Arthurs Pass

from Dowrick (personal comm.)
2 depth: $\mathrm{S}$ shallow upper crustal; $\mathrm{C}$ undifferentiated crustal; $\mathrm{R}$ restricted depth

K=Kaikoura $\quad$ MC=Mount Cook HS=Hanmer Springs

$\mathrm{T}=$ Twizel
T=Twizel 


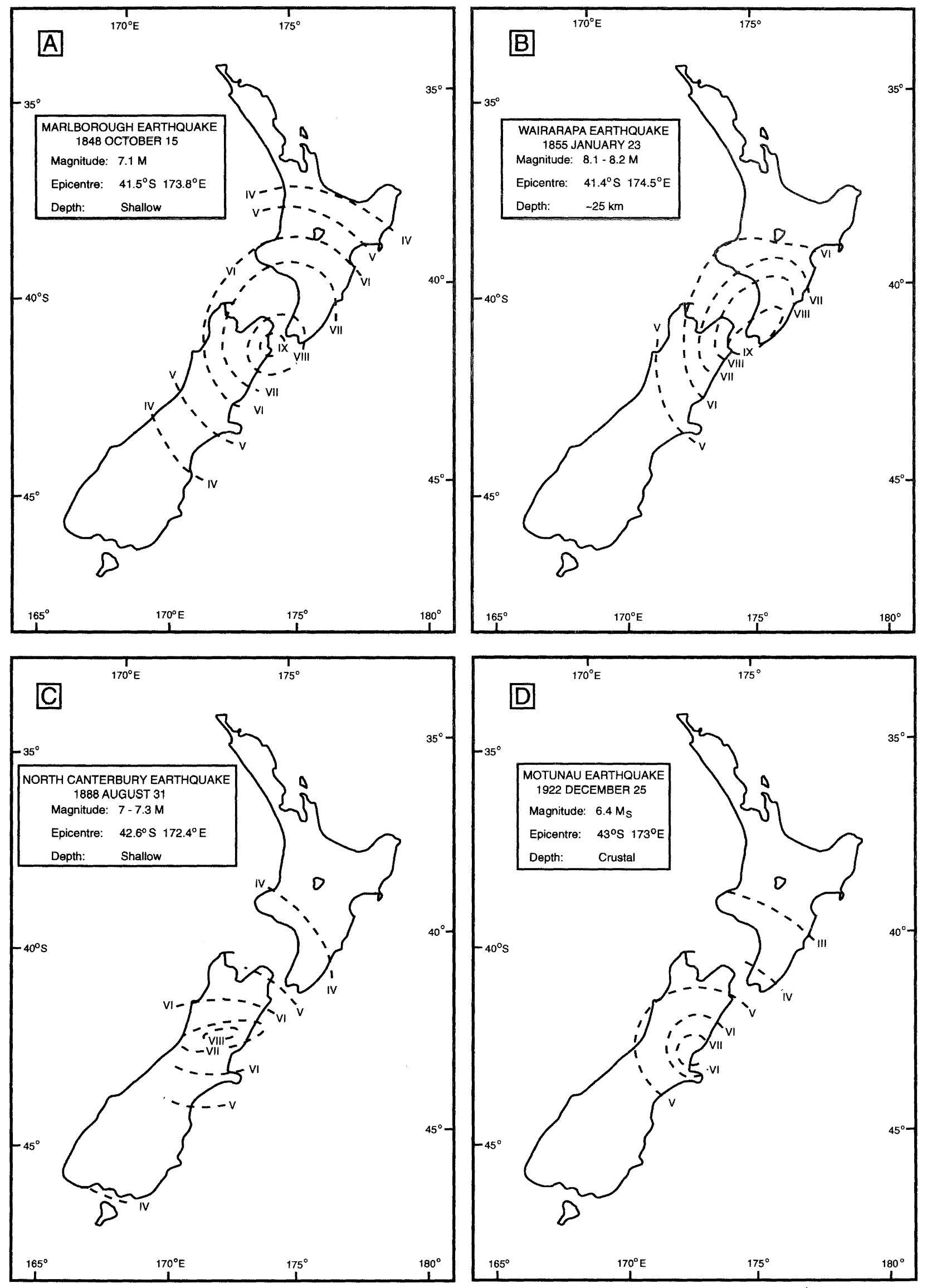

Figure 7: Available isoseismal maps of significant historic earthquakes listed in Tables 9 and 10. (A): after Grapes and Downes (1997); (B): after Downes (1995); (C): after Downes (1995) and Cowan (1991); (D-F): after Downes (1995); and (H) after Eiby (1953) and Downes (1995). 


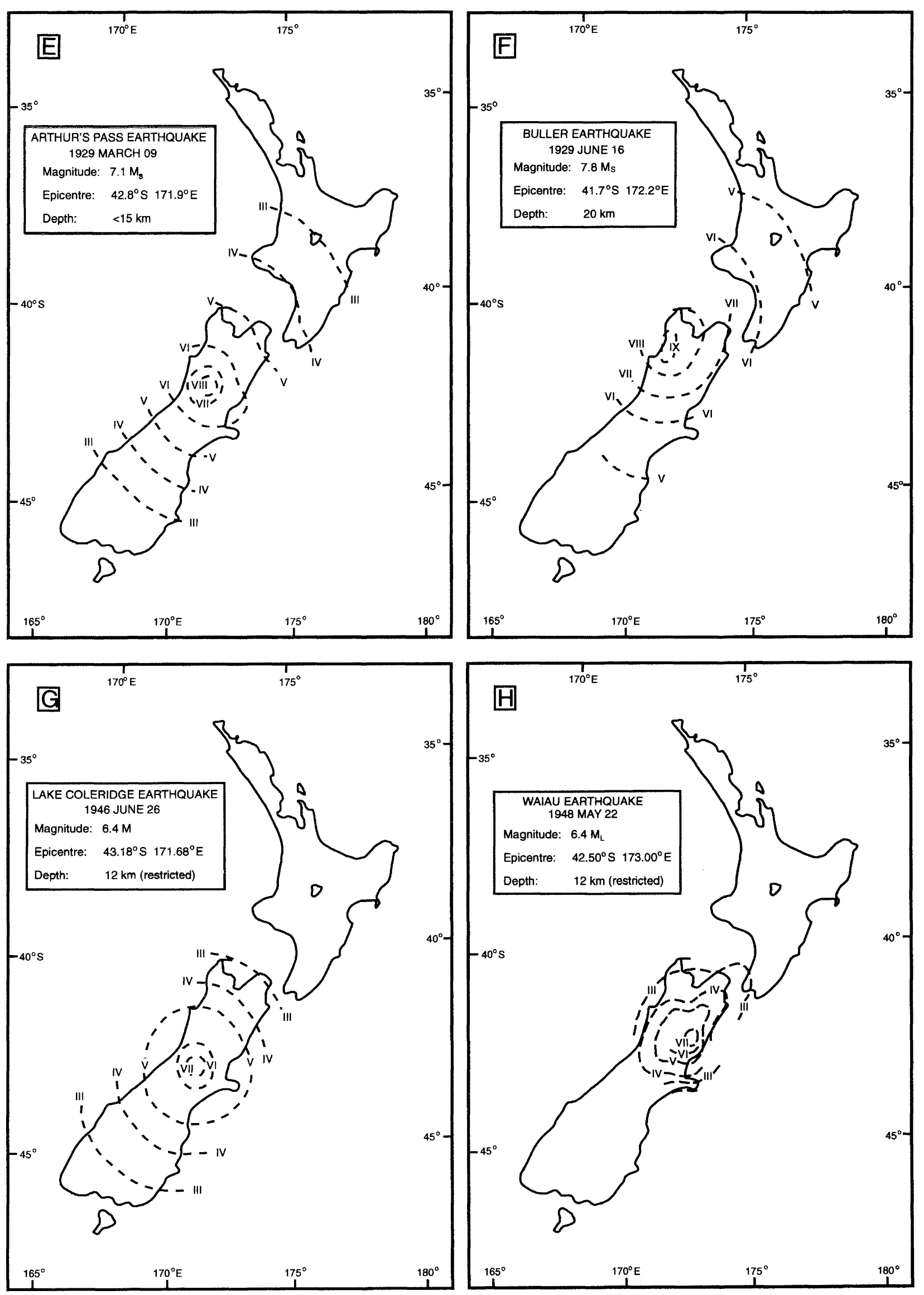

Figure 7 continued. 
Table 10: Estimates of felt intensities from other database sources for significant historical earthquakes in the Canterbury region.

\begin{tabular}{|c|c|c|c|c|c|c|c|}
\hline Year & Date & Name & $\begin{array}{r}\text { Dib } \\
\text { C }\end{array}$ & $\begin{array}{l}\text { et al. } \\
\text { (MM) } \\
\text { Lytt }\end{array}$ & $\begin{array}{l}980) \\
\mathrm{Ak}\end{array}$ & Others (MM) & $\begin{array}{l}\text { Iso. } \\
\text { Map }\end{array}$ \\
\hline 1869 & Jun 04 & [New Brighton] & $7-8$ & 6 & \multirow{8}{*}{5} & \multirow{7}{*}{$\begin{array}{l}\text { C } 6-7 \text {, Lytt 5-6, } \\
\text { Ak } 5 \text { (Cowan, 1991) }\end{array}$} & \multirow{8}{*}{$\begin{array}{l}\sqrt{ } \\
\sqrt{ } \\
\sqrt{ }\end{array}$} \\
\hline 1870 & Aug 31 & & $6-7$ & $6-7$ & & & \\
\hline 1881 & Dec 04 & & $6-7$ & $5-6$ & & & \\
\hline 1888 & Aug 31 & Nth Canterbury & 7 & $6-7$ & & & \\
\hline 1901 & Nov 15 & Cheviot & 7 & $5-6$ & & & \\
\hline 1922 & $\operatorname{Dec} 25$ & Motunau & 7 & 7 & & & \\
\hline 1929 & Mar 09 & Arthurs Pass & $6-7$ & $5-6$ & & & \\
\hline 1929 & Jun 16 & Buller & 7 & $5-6$ & & C 5 - 6 (Dowrick, 1994) & \\
\hline
\end{tabular}

Notes:

$\mathrm{C}=$ Christchurch

\section{SUMMARY AND CONCLUSIONS}

The Canterbury region is located within a wide zone of active earth deformation associated with the oblique collision between the Australian and Pacific tectonic plates east of the Alpine fault. Based on geological evidence, we define nine structural domains in which the styles of deformation are similar and related. There is a progressive decrease in fault activity across the region to the southeast, from a maximum in the Marlborough Fault Zone (Domain 1: strike-slip faulting), and the Southern Alps Zone (Domain 8: thrust/reverse faulting), which both border the Alpine fault (Domain 9). The Porters Pass-Amberley Fault Zone (Domain 3: strike-slip and thrust/reverse faulting), and the North Canterbury Fold and Thrust Belt (Domain 4: thrust/reverse faulting), together represent an intermediate level of activity associated with the southward widening of the plate boundary zone. Adjoining domains to the north and south, such as the West Culverden Fault Zone (Domain 2: thrust /reverse faulting) and the Mt Hutt-Mt Peel Fault Zone (Domain 5: thrust/reverse faulting), have a lower rate of activity. The least active domains include the poorly known area of basement and cover rocks buried beneath the thick Canterbury Plains gravels (Domain 7) and the south Canterbury foothills area, extending southeast to the Waitaki River (Domain 6: thrust/reverse faulting).

We identify approximately 90 major earthquake sources within Canterbury and the immediately surrounding regions of South Island, New Zealand, and have characterised these in terms of fault geometry and type (fault dimensions, dip and sense of slip); and activity (slip rate, single event displacement, recurrence intervals, timing of last rupture). Several of the major, active faults are segmented, and therefore represent multiple earthquake sources. The Alpine fault is considered capable of generating a great earthquake (>Magnitude 8), and while located outside the region, represents a significant earthquake hazard with respect to the entire Canterbury region.

We have included a review of significant historic earthquakes which have impacted the Canterbury region (Christchurch earthquakes 1869 and 1870; North Canterbury 1888; Cheviot 1902; Motunau 1922; Buller 1929; Arthurs Pass 1929 and 1994). This, combined with the instrumentally recorded database of seismicity (1943 to 1997), has provided a $\sim 150$ year perspective of the geographic occurrence of earthquakes, and more importantly their felt effects across the region.

The integrated geological and seismological data from this study are used to undertake a Probabilistic Seismic Hazard Assessment for the Canterbury region, and this is presented in a following companion paper in this issue of the Bulletin (Stirling et al. this volume).

\section{ACKNOWLEDGEMENTS}

This paper is distilled from a more comprehensive report prepared in 1998 for the former Canterbury Regional Council (now Environment Canterbury). We thank Peter Kingsbury and Environment Canterbury for funding the Stage 1 (Part A) of the Earthquake Hazard and Risk Assessment Study, and for the numerous discussions and review comments. We also thank Alan Hull (Formerly GNS) and Kelvin Berryman (GNS) for their input by way of discussion and useful comments in the preparation of the original 1998 report. Similarly, we acknowledge the excellent assistance of Chris Chamberlain and Richard Jongens (both $U$ of $C$ ) with original data compilation and report preparation. We also particularly wish to acknowledge the thorough and detailed review of the manuscript by Robert Langridge, providing numerous suggestions for its improvement.

\section{REFERENCES}

Abercrombie, R.; Webb, T.H.; Robinson, R.; McGinty, P.; Mori, J.; Beavan, R. J. (2000): "The enigma of the Arthur's Pass, New Zealand, earthquake 1: reconciling a variety of data from an unusual earthquake sequence". Journal of Geophysical Research. 105, B7: 16119-16137.

Adams J. (1980): "Paleoseismicity of the Alpine fault seismic gap”. Geology 8: 72-76. 
Anderson, J.G.; Wesnousky, S.G.; Stirling, M.W. (1996): "Earthquake size as a function of fault slip rate". Bulletin of the Seismological Society of America 86: 683-690.

Anderson, H.; Webb, T. (1994): "New Zealand seismicity: patterns revealed by the upgraded National Seismograph Network". NZ Journal of Geology and Geophysics 37: 477493

Armstrong, M. J. (2000): "Geomorphology and geophysical investigation of the effects of active tectonic deformation on the hydrogeology of North Culverden Basin, North Canterbury". Unpublished $\mathrm{PhD}$ thesis, University of Canterbury Library, Christchurch, New Zealand.

Barnes, P.M. (1993): "Structural styles and sedimentation at the southern termination of the Hikurangi subduction zone, offshore north Canterbury, New Zealand". Unpublished PhD thesis, University of Canterbury Library, Christchurch, New Zealand.

Barnes, P. M. (1996): “Active folding of Pleistocene unconformities on the edge of the Australian-Pacific plate boundary zone, offshore North Canterbury, New Zealand". Tectonics 15: 623-640.

Barnes, P.M.; Mercier de Lapinay, B.; Collot, J.E.; Delteil, J.; Audru, J-C. (1998): "Strain partitioning in the transition area between oblique subduction and continental collision, Hikurangi margin, New Zealand". Tectonics 17: 534-557.

Barnes, P.M.; Audru, J-C. (1999): "Recognition of active strike-slip faulting from high-resolution reflection profiles: eastern Marlborough fault system, New Zealand". Geological Society of America Bulletin 111: 538-559.

Barrell, D.J.A.; Forsyth, P.J.; McSaveney, M.J. (1996): "Quaternary geology of the Rangitata Fan, Canterbury Plains, New Zealand". Institute of Geological and Nuclear Sciences Report 96/23: 67p.

Berrill, J. B., Mulqueen, P. C. Ooi, E. T. C. (1994): "Liquefaction at Kaiapoi in the 1901 Cheviot, New Zealand, earthquake". Bulletin of the New Zealand National Society for Earthquake Engineering 27: 178-189.

Berryman, K. R.; Beanland, S.; Cooper, A.F.; Cutten, H.N.; Norris, R.J.; Wood, P.R. (1992): "The Alpine fault, New Zealand: variations in Quaternary structural style and geomorphic expression". Annales Tectonicae VI: 126-163.

Berryman, K. R.; Cooper, A.; Norris, R.J.; Sutherland, R.; Villamor, P. (1998): "Paleoseismic Investigation of the Alpine fault at Haast and Okuru". Geological Society of NZ and NZ Geophysical Society, Joint Annual Conference, Christchurch, New Zealand: 44

Bonilla, M.G.; Mark, R.K.; Lienkaemper, J.J. (1984): "Statistical relations among earthquake magnitude, surface rupture length, and surface fault displacement". Bulletin of the Seismological Society of America 74: 2379-2411.

Bull, W.B. (1991): "Geomorphic responses to climate change”. Oxford University Press, New York. 326pp.
Bull, W.B. (1996): "Prehistorical earthquakes on the Alpine fault, New Zealand". Journal of Geophysical Research 101, B3: $6037-6050$.

Bull, W.B., Brandon, M.T. (1998): "Lichen dating of earthquake generated regional rockfall events, Southern Alps, New Zealand". Geological Society of America Bulletin 110: 60-84.

Bull, W.B.; Cooper, A.F. (1989): "Uplifted marine terraces along the Alpine fault, New Zealand". Science 234: 1225 1228.

Campbell, J.K. (1973): "Displacement data from the Alpine fault at Lake Rotoiti and its relevance to glacial chronology and the tempo of tectonism". IXth Congress INQUA (International Union for Quaternary Research) Abstracts Volume: 57-58.

Cooper, A.F.; Norris R.J. (1990): "Estimates for the timing of the last coseismic displacement on the Alpine fault, northern Fiordland, New Zealand". New Zealand Journal of Geology and Geophysics 33: 303-307.

Cowan, H.A. (1989): "An evaluation of the Late Quaternary displacements and seismic hazard associated with the Hope and Kakapo faults, Amuri District, north Canterbury". Unpublished MSc Engineering Geology Thesis, University of Canterbury Library, Christchurch, New Zealand.

Cowan, H.A. (1990): "Late Quaternary displacements on the Hope fault at Glynn Wye, North Canterbury". New Zealand Journal of Geology and Geophysics 33: 285-293.

Cowan, H.A. (1991): "The North Canterbury earthquake of 1 September, 1888". Journal of the Royal Society of N.Z. 21: $1-12$.

Cowan, H.A. (1992): "Structure, seismicity and tector 301 the Porter's Pass-Amberley Fault Zone, North Canteıuury, New Zealand". PhD thesis, University of Canterbury, Christchurch, New Zealand.

Cowan, H.A.; McGlone, M.S. (1991): "Late Holocene displacements and characteristic earthquakes on the Hope River segment of the Hope fault, New Zealand". Journal of the Royal Society of N.Z. 21: 373-384.

Cowan, H.A., Nicol, A., Tonkin, P. (1996): “A comparison of historical and paleoseismicity in a newly formed fault zone and a mature fault zone, North Canterbury, New Zealand". Journal of Geophysical Research 101/B3: 6021-6036.

Cox, S.C.; Findlay, R.H. (1995): "The Main Divide Fault Zone and its role in formation of the Southern Alps". New Zealand Journal of Geology and Geophysics 38: 489-499.

Davey, F.J.; Henyey, T.; Kleffmann, S.; Melhuish, A.; Okaya, D.; Stern, T.A.; Woodward, D.J. (1995): "Crustal reflections from the Alpine Fault Zone, South Island, New Zealand". New Zealand Journal of Geology and Geophysics 38: 601-604.

DeMets, C.; Gordon, R.G.; Argus, D.F.; and Stein, S. (1990): 
"Current plate motions". Geophysical Journal International 101: 425-478.

Delteil, J.; Collot, J-Y.; Wood, R.; Herzer, R.; Calmant, S.; Christoffel, D.; Coffin, M.; Ferriere, J.; Lamarche, G.; Lebrun, J-F.; Mauffret, A.; Pontoise, B.; Popoff, M.; Ruellan, E.; Sosson, M.; Sutherland, R. (1996): "From strike-slip faulting to oblique subduction: a survey of the AlpinePuysegur Trench transition, New Zealand, Results of Cruise Geodynz-Sud Leg 2". Marine Geophysical Researches 18: 383-399.

Dibble, R.R.; Ansell, J.H.; Berrill, J.B. (1980): "Report on a study of seismic risk for BP New Zealand Ltd sites at Woolston and Lyttelton". Unpublished report to BP NZ Ltd.

Downes, G. L. (1995): "Atlas of isoseismal maps of New Zealand earthquakes". Institute of Geological \& Nuclear Sciences monograph 11 .

Dowrick, D. J., Smith, E. G. C. (1990): "Surface wave magnitudes of some New Zealand earthquakes 1901-1988". Bulletin of the New Zealand National Society for Earthquake Engineering 24: 210-224.

Dowrick, D.J. (1992): "Attenuation of Modified Mercalli Intensity in New Zealand earthquakes". Earthquake Engineering and Structural Dynamics 21: 181-196.

Dowrick, D.J. (1994): "Damage and intensities in the Magnitude 7.81929 Murchison, New Zealand earthquake". Bulletin of the New Zealand National Society for Earthquake Engineering 27: 190-204.

Eberhart-Phillips, D. (1995): "Examination of seismicity in the central Alpine fault region, South Island, New Zealand". New Zealand Journal of Geology and Geophyics 38: 571578 .

Eberhart-Phillips, D.; Reyners, M. (1997): "Continental subduction and three dimensional crustal structure: the northern South Island, New Zealand". Journal of Geophysical Research 102, B6: 11843-11861.

Eiby, G. A. (1953): "The Waiau earthquakes of May, 1948". Proceedings of the 7th Pacific Congress 2: 622-628.

Eiby, G. A. (1968): "Annotated list of New Zealand earthquakes, 1460-1965”. New Zealand Journal of Geology and Geophysics 11: 630-647.

Eiby, G. A. (1980): "The Marlborough earthquakes of 1848 ". DSIR Bulletin 225.

Eiby, G. A. (1990): "The Lake Coleridge earthquakes of 1946". Bulletin of the New Zealand National Society for Earthquake Engineering 23: 150-158.

Enys, J. D. (1882): "On earthquake phenomena". Transactions \& Proceedings of the New Zealand Institute 15: 533.

Elder, D.M.; McCahon, I.F.; Yetton, M.D. (1991): “The earthquake hazard in Christchurch: a detailed evaluation". Unpublished Report to Earthquake Commission.
Elvy, J. M. (1999): "Tectonic geomorphology and paleoseismic investigations, Mt Hutt district, Canterbury". Unpublished MSc thesis, University of Canterbury Library, Christchurch, New Zealand.

Eusden, J.D.; Pettinga, J.R.; Campbell, J.K. (2000): "Structural evolution and landscape development of a transpressive duplex on the Hope fault, North Canterbury, New Zealand". New Zealand Journal of Geology and Geophysics 43: 391-404.

Freund, R. (1971): "The Hope fault: a strike-slip fault in New Zealand". New Zealand Geological Survey Bulletin 86.

Gair, H.S. (1967): "Sheet 20 Mt Cook (1st edition) Geological Map of New Zealand 1:250,000". Department of Scientific and Industrial Research, Wellington, New Zealand.

Garlick, R. (1992): "Lees Valley fault". Unpublished B.Sc(Hons) dissertation, University of Canterbury Library.

Gledhill, K., Robinson, R., Webb, T., Abercrombie, R., Beavan, J., Cousins, J., Eberhart-Phillips, D. (2000): "The Mw 6.2 Cass, New Zealand, earthquake of 24 November, 1995: reverse faulting in a strike-slip region". New Zealand Journal of Geology and Geophysics 43: 255-269.

Grapes, R., Downes, G. (1997): "The 1855 Wairarapa, New Zealand, earthquake - analysis of historical data". Bulletin of the New Zealand National Society for Earthquake Engineering 30: 273-367.

Grapes R.; Little, T.; Downes, G. (1998): "Rupturing of the Awatere fault during the 1848 October 16 Marlborough earthquake, New Zealand: historical and present day evidence". New Zealand Journal of Geology and Geophysics 41: 387-399.

Hicks, S.R. (1989): "Structure of the Canterbury Plains, New Zealand, from gravity modeling". Geophysics Division Research Report 222. Department of Scientific and Industrial Research, Wellington.

Kieckhefer, R.M. (1979): Sheets M31D, N31A, N31C, and parts of M32A, and M32B Leader Dale (1st edition), and Sheets O30C and O31A Lake McRae (1st edition) "Late Quaternary Tectonic Map of New Zealand 1:50,000" 3 Maps and Text (28p). Department of Scientific and Industrial Research, Wellington, New Zealand.

Kingsbury, P.A.; Pettinga, J.R.; Van Dissen, R.J. (this volume): "Earthquake hazard and risk assessment study for the Canterbury region, South Island, New Zealand: Outline of programme development". Bulletin of the New Zealand National Society for Earthquake Engineering.

Kirkaldy, P.H.S.; Thomas, E.G. (1963): "Final report on a seismic survey in the Canterbury Plains area of New Zealand". BP Shell and Todd Petroleum Development Ltd. N.Z. Geological Survey Unpublished Open-File Petroleum Report 328.

Kleffmann, S.; Davey, F.; Melhuish, A.; Okaya, D.; Stern, T. (1998): "Crustal structure in the central South Island, New 
(1998): "Crustal structure in the central South Island, New Zealand, from the Lake Pukaki seismic experiment". New Zealand Journal of Geology and Geophysics 41: 39-49.

Knuepfer, P.L.K. (1984): "Tectonic geomorphology and present-day tectonics of the Alpine shear system, South Island, New Zealand". Unpublished Ph.D. thesis, University of Arizona, U.S.A.

Knuepfer, P.L.K. (1992): "Temporal variations in latest Quaternary slip across the Australian-Pacific plate boundary, northeastern South Island, New Zealand". Tectonics 11: 449464.

Lensen, G.J. (1968): Analysis of progressive fault displacement during down-cutting at the Branch River terraces, South Island, New Zealand. Bulletin of the Geological Society of America 79: 545-556.

Lewis, K.B., Pettinga, J.R. (1993): "The emerging imbricate frontal wedge of the Hikurangi Margin". in: P.F. Ballance (editor) South Pacific Sedimentary Basins (Chapter 13), Sedimentary Basins of the World 2; Elsevier, Amsterdam: 225-250.

Litchfield, N.J. (1995): "Structure and tectonic geomorphology of the Lowry Peaks Range, Waikari Valley District, north Canterbury". Unpublished MSc(Hons) thesis, University of Canterbury Library, Christchurch.

Little, T.A.; Grapes, R.H.; Berger, G.W. (1998): "Late Quaternary strike-slip on the eastern part of the Awatere fault, South Island, New Zealand". Bulletin of the Geological Society of America 110, 2-23.

McCalpin, J.P. (1996a): "Paleoseismology". International Geophysics Series No 62, Academic Press, San Diego.

McCalpin, J.P. (1996b): “Tectonic geomorphology and Holocene paleoseismicity of the Molesworth section of the Awatere fault, South Island, New Zealand". New Zealand Journal of Geology and Geophysics 39: 33-50.

McKay, A. (1890): "On the earthquakes of September 1888, in the Amuri and Marlborough Districts of the South Island". New Zealand Geological Survey Report of Geological Explorations 20: 1-16.

McMorran, T.J. (1991): "The Hope fault at Hossack Station east of Hanmer Basin, North Canterbury". Unpublished MSc thesis, University of Canterbury Library, Christchurch.

Mould, R.J. (1992): "Structure and kinematics of Late Cenozoic deformation along the western margin of the Culverden Basin, north Canterbury, New Zealand". Unpublished MSc (Hons) thesis, University of Canterbury Library, Christchurch.

Mutch, A.R. (1963): Sheet 23 Oamaru (1st edition) Geological Map of New Zealand 1:250,000. Department of Scientific and Industrial Research, Wellington, New Zealand.

Nicol, A. (1991): "Structural styles and kinematics of deformation on the edge of the New Zealand plate boundary zone, mid-Waipara region, North Canterbury". Unpublished
Ph.D thesis, University of Canterbury Library.

Nicol, A.; Alloway, B.; Tonkin, P. (1994): "Rates of deformation, uplift, and landscape development associated with active folding in the Waipara area of North Canterbury, New Zealand". Tectonics 13: 1327-1344.

Norris, R.J. (1999): "Earthquakes on the Alpine fault from scientific and political perspectives". Geological Society of New Zealand Miscellaneous Publication 95A (abstract only): 136.

Norris, R.J.; Cooper, A.F. (1997): "Erosional control on the structural evolution of the range front faulting on the Alpine fault". Geological Society of New Zealand Miscellaneous Publication 107A (abstract only): 126.

Norris, R.J.; Cooper, A.F. (2001): "Late Quaternary slip rates and slip partitioning on the Alpine fault, New Zealand". Journal of Structural Geology 23: 507-520.

Norris, R.J.; Koons, P.O.; Cooper, A.F. (1990): "The obliquely-convergent boundary in the South Island of New Zealand: implications for ancient collision zones". Journal of Structural Geology 12: 715-725.

Oliver, P. J.; Keene, H. W. (1989): Sheet K36 AC \& part sheet K 35-Mt Somers. Geological map of New Zealand 1:50:000. Map and notes. Department of Scientific and Industrial Research, Wellington, New Zealand.

Oliver, P. J.; Keene, H. W. (1990): Sheet J36 BD \& part sheet J35-Clearwater. Geological Map of New Zealand 1:50:000. Map and notes. Department of Scientific and Industrial Research, Wellington, New Zealand.

Pettinga, J. R., Armstrong, M. J. (1998): "North Canterbury active tectonics and earthquake hazards". Geological Society of NZ Miscellaneous Publication 101B: Field Trip Guides. M.G. Laird (Ed.) Field trip 3: 28p.

Pettinga, J.R., Wise, D.U. (1994): "Paleostress orientation adjacent to the Alpine fault of New Zealand: broader implications from fault analysis near Nelson, South Island, New Zealand". Journal of Geophysical Research 99/B2; 2727-2736.

Pettinga, J.R.; Chamberlain, C.G.; Yetton, M.D.; Van Dissen, R.J.; Downes, G. (1998): "Earthquake Source Identification and Characterisation: Stage 1 (Part A) Earthquake Hazard and Risk Assessment Study". Canterbury Regional Council CRC Publication No. U98/10: 121pages and 6 Appendices.

Pope, J.G. (1994): "Secondary structures, Holocene displacements and paleoseismicity of the Conway segment of the Hope fault, Greenburn Stream to Sawyers Creek". Unpublished BSc(Hons) project Geological Sciences Library, University of Canterbury, Christchurch New Zealand.

Reyners, M.E. (1989): "New Zealand seismicity 1964-87: an interpretation". New Zealand Journal of Geology Geophysics 32: 307-315.

Reyners, M. E. (1998): "Plate coupling and the hazard of large subduction thrust earthquakes at the Hikurangi 
subduction zone, New Zealand". New Zealand Journal of Geology and Geophysics 41: 343-354.

Reyners, M.E., Cowan, H.A. (1993): "The transition from subduction to continental collision: crustal structure in the North Canterbury region, New Zealand". Geophysical Journal International 115; 1124-1136.

Scholz, C.H. (1990): "The Mechanics of Earthquakes and Faulting". Cambridge University Press, 439p.

Schwartz, D.P.; Coppersmith, K.J. (1984): "Fault behaviour and characteristic earthquakes: examples from Wasatch and San Andreas faults". Journal of Geophysical Research 89: 5681-5698.

Schwartz, D.P.; Coppersmith, K.J. (1986): "Seismic hazards: new trends in analysis using geologic data". In: "Active Tectonics: Studies in Geophysics". National Academy Press, Washington D.C.: 215-230.

Sibson, R.H. (1989): "Earthquake faulting as a structural process". Journal of Structural Geology 11: 1-14.

Sieh, K.E. (1984): "Lateral offsets and revised dates of large prehistoric earthquakes at Pallett Creek, Southern California". Journal of Geophysical Research 89/B9: 76417670

Sieh, K.E.; Stuiver, M.; Brillinger, D. (1989): “A more precise chronology of earthquakes produced by the San Andreas fault in southern California". Journal of Geophysical Research 94: 603-623.

Simpson, R.J. (1995): "The seaward segment of the Hope Fault, Seaward Kaikoura Ranges, Southeast Marlborough". Unpublished BSc(Hons) project, University of Canterbury Geological Sciences Library.

Simpson, G.D.H.; Cooper, A.F.; Norris, R.J. (1994): "Late Quaternary evolution of the Alpine fault zone at Paringa, South Westland, New Zealand". New Zealand Journal of Geology and Geophysics 37: 49-58.

Smith, W.D.; Berryman, K.R. (1983): "Revised estimates of earthquake hazard in New Zealand". Bulletin of the New Zealand National Society for Earthquake Engineering 16: 259-272.

Smith, W.D.; Berryman K.R. (1986): "Earthquake hazard in New Zealand: inferences from seismology and geology". Royal Society of New Zealand Bulletin 24: 223-243.

Speight, R. (1933): "The Arthur's Pass earthquake of 9th March, 1929". New Zealand Journal of Science and Technology 15: 173-182.

Stirling M.; Wesnousky S.G.; and Berryman, K.R. (1998): "Probabilistic seismic hazard analysis of New Zealand". New Zealand Journal of Geology and Geophysics 41: 355-375.

Stirling, M.; Pettinga, J.R.; Berryman, K. R.; Yetton, M.D (this volume): Probabilistic Seismic Hazard Assessment of the Canterbury Region. New Zealand. Bulletin of the New Zealand Society for Earthquake Engineering.
Stirling, M.; Yetton, M.D.; Pettinga, J.R.; Berryman K. R.; Downes, G. (1999): "Probabilistic Seismic Hazard Assessment and Earthquake Scenarios for the Canterbury Region, and Historic Earthquakes in Christchurch". Stage 1 (Part B) Earthquake Hazard and Risk Assessment Study, Canterbury Regional Council CRC Publication No. U99/18: 79 pages and 6 Appendices.

Sutherland R.; Norris, R.J. (1995): "Late Quaternary displacement rate, paleoseismicity, and geomorphic evolution of the Alpine Fault: evidence from Hokuri Creek, South Westland, New Zealand". New Zealand Journal of Geology and Geophysics 38: 419-430.

Toshinawa, T.; Taber, J.J.; Berrill, J.B. (1997): "Distribution of ground-motion intensity inferred from questionnaire survey, earthquake recordings, and micrometer measurements - a case study in Christchurch, New Zealand, during the 1994 Arthurs Pass earthquake". Bulletin of the Seismological Society of America 87: 356-369.

Van Dissen, R.J. (1989): "Late Quaternary faulting in the Kaikoura region, southeastern Marlborough, New Zealand". Unpublished MS thesis, Oregon State University, USA: 72p.

Van Dissen, R.J.; Nicol, A. (1998): "Paleoseismicity of the middle Clarence Valley section of the Clarence fault, Marlborough, New Zealand". Geological Society of NZ Miscellaneous Publication 101 A: 233.

Van Dissen, R.; Yeats, R.S. (1991): "Hope fault, Jordan thrust, and uplift of the Seaward Kaikoura Range, New Zealand". Geology 19: 393-396.

Van Dissen, R.J.; Hull, A.G.; Read, S.A.L. (1993): "Timing of some large Holocene earthquakes on the Ostler fault, New Zealand". Proceedings of the CRCM, Kobe, December 1993: 381-386.

Wallace, R.E. (1981): "Active faults, paleoseismology and earthquake hazards in the western United States; in: Earthquake prediction: an International Review" (D.W Simpson and P.G. Richards eds) Maurice Ewing Series 4, American Geophysical Union, Washington, D.C.: 209-216.

Walcott, R.I. (1998): "Modes of oblique compression: Late Cenozoic tectonics of the South Island of New Zealand". Reviews of Geophysics 36: 1-26

Wells, A. (1998): "Landscape disturbance history in Westland, New Zealand: The importance of infrequent earthquakes along the Alpine fault". Unpublished $\mathrm{PhD}$ thesis, Lincoln University, Lincoln, Christchurch.

Wells, A.; Stewart, G.H.; Duncan, R.P. (1998): "Evidence of widespread, synchronous, disturbance-initiated forest establishment in Westland, New Zealand". Journal of the Royal Society of New Zealand 28: 333-345.

Wells, A; Yetton, M.D.; Stewart, G.H.; Duncan, R.P. (1999): "Prehistoric dates of the most recent Alpine fault earthquakes, New Zealand”. Geology, 27: 995-998.

Wells, D.L.; Coppersmith, K.J. (1994): "New empirical 
relationships among magnitude, rupture length, rupture width, rupture area, and surface displacement". Bulletin of the Seismological Society of America 84: 974-1002.

Wood, R., Pettinga, J.R., Bannister, S., Lamarche, G., McMorran T. (1994): "Structure of the Hanmer strike-slip basin, Hope fault, New Zealand". Bulletin of the Geological Society of America 106: 1459-1473.

Working Group on California Earthquake Probabilities (1995): Seismic hazards in southern California: Probable earthquakes 1994-2024. Bulletin of the Seismological Society of America 85: 379-439.

Wright, C.A. (1998): "Geology and paleoseismology of the central Alpine fault, New Zealand". Unpublished MSc Thesis. University of Otago, Dunedin, New Zealand.

Wright, C.A.; Norris, R.J.; Cooper, A.F. (1998): "Paleoseismological history of the Central Alpine fault". Geological Society of NZ Miscellaneous Publication 101A (Abstract only): 249.

Yang, J.S. (1991): "The Kakapo fault - a major active dextral fault in the central North Canterbury-Buller regions of New Zealand". New Zealand Journal of Geology and Geophysics 34: 137-143.

Yetton, M.D. (2000): "The probability and consequences of the next Alpine fault earthquake". Unpublished PhD Thesis. University of Canterbury library, Christchurch.

Yetton, M.D.; Wells, A. (1998): "Paleoseismic history of the central and northern Alpine fault". Geological Society of NZ Miscellaneous Publication 101A: 250.

Yetton, M.D.; Wells, A.; Traylen, N.J. (1998): "The probability and consequences of the next Alpine fault earthquake". Earthquake Commission Research Report 95/193: 161p.

Yousif, H.S. (1987): "The application of remote sensing to geomorphological neotectonic mapping in north Canterbury, New Zealand". PhD thesis, University of Canterbury Library, Christchurch, New Zealand.

\section{APPENDIX:}

Marlborough Earthquake: October 16, 1848:

The 1848 Marlborough earthquake, centred in the Awatere area, produced MM9-10 intensities in the epicentral area and was felt from south of Auckland to at least Christchurch (Eiby 1980). At Kaikoura, the intensity is likely to have been MM7 or MM8. In northern Canterbury intensities of MM7 were experienced. In Christchurch the intensity was MM5. In a recently published study by Grapes et al. (1998) this earthquake has been related to surface rupture of the Awatere fault.

\section{Wairarapa Earthquake: January 23, 1855:}

This earthquake is the largest in New Zealands' short historical record and it was felt over most of the land area of New Zealand. The earthquake caused surface rupture of the Wairarapa fault accompanied by uplift of up to $6 \mathrm{~m}$ to the west of the fault (Grapes and Downes 1997). The earthquake's effects decrease south of Cook Strait, about which intensities of MM9 and MM10 were experienced. The Canterbury Region experienced a range of intensities from MM4 in South Canterbury to probably MM7 in Kaikoura. In Christchurch, only minor household damage occurred, but around the Waiau area at least one chimney fell (MM6-7). Several large aftershocks were felt strongly around Kekerengu, $50 \mathrm{~km}$ north of Kaikoura, and were possibly located close to Kekerengu rather than in the rupture zone of the mainshock (Grapes and Downes 1997). It is estimated that intensities caused by these earthquakes were MM6, possibly MM7, at Kaikoura.

Christchurch Earthquake (formerly the New Brighton Earthquake): June 04, 1869:

Eiby (1968) lists this event as occurring at Banks Peninsula, with an intensity of MM7 at Christchurch and this location was used in the Earthquake catalogue until the review report by Stirling et al. (1999). According to the unpublished report of Dibble et al. (1980), which was used in compiling the Elder $e$ t al. (1991) report, the earthquake caused the general destruction of chimneys and some damage to masonry (MM7, possibly MM8) in parts of Christchurch. Lyttelton was less damaged than Christchurch, with only one fallen chimney (MM6) and outside these areas the intensity decreased rapidly, implying a shallow local shock.

The reports of this earthquake that IGNS held prior to 1999 appeared to be less extensive than those used by Dibble $e t$ al. (1980), and included no Christchurch or Lyttelton newspapers. For the most part these reports agree with Dibble et al's and Elder et al. (1991) description of the extent of damage to buildings and also indicate that aftershocks were felt for several days and that the duration of strong shaking was 3-4 seconds, substantiating Dibble et al's conclusion that the earthquake was shallow and local. One report suggests that settlement may have occurred in the Heathcote River, i.e. "since the recent heavy earthquake, the tide runs further up the Heathcote River than previously" (Weekly News June 26, 1869).

Elder et al. (1991) name the earthquake, "the New Brighton earthquake", and suggested a magnitude of M 5.75, assigning an epicentre $10 \mathrm{~km}$ from Christchurch city centre. The reports of the earthquake that IGNS held proved insufficient to assign a reliable epicentre and magnitude and this resulted in these parameters differing from those of Dibble et al. (1980). Accordingly, this earthquake was researched in more detail as part of the Stage 1 (Part B) of the CRC Earthquake and Risk Assessment Study, and as a consequence was renamed the Christchurch Earthquake, with an epicentral location within the city limits (refer Stirling et al. 1999) This epicentral location is here included in Figure 6. This earthquake is probably the most destructive to have been experienced in Christchurch. Stirling et al. have also compiled the first isoseismal plot for this earthquake.

\section{Christchurch Earthquake August 31, 1870:}

As with the previous "Christchurch" earthquake, there are only a small number of accounts of the 1870 earthquake held within IGNS files and, in 1997, very little was known about this event prior to the Stirling et al. (1999) report. According to Dibble et al. (1980) it caused most damage in Christchurch and Lyttelton where several chimneys were cracked or fell 
MM7). It was felt in Oamaru, Greymouth and Dunedin Dibble et al. consider that the distribution of intensity is consistent with a magnitude 6.5 shock at a distance of $50 \mathrm{~km}$ from Christchurch, probably to the east, rather than to the southeast where the epicentre in the Earthquake Catalogue is placed, following Eiby (1968). In the review by Stirling et al. (1999) a new epicentral location is proposed, close to Lake Ellesmere, and south of Banks Peninsula. This location is also included here in Figure 6. These authors also have prepared the first isoseismal plot for this event.

\section{December 5 1881:}

The Earthquake Catalogue had adopted the epicentre suggested in Eiby (1968). However, Dibble et al. (1980) investigated newspaper reports for this event and concluded that its magnitude was about 6.2-6.3 and the epicentre was close to Castle Hill, $80 \mathrm{~km}$ to the west of Christchurch. The intensity at Castle Hill reached MM7, possibly MM8. Sand fountaining occurred in Lake Sarah near Cass (Enys 1882). Several chimneys were damaged in Christchurch and some stone was shaken from the Cathedral spire (MM6, possibly MM7), while Lyttelton experienced intensities of at most MM5. Stirling et al. (1999) also reviewed this event and have placed the epicentre in the Cass- Castle Hill region of inland Canterbury (refer Figure 6), and have also prepared a tentative isoseismal map.

\section{North Canterbury: September 1, 1888:}

The North Canterbury Earthquake of 1888 is one of the largest earthquakes (M 7.0-7.3) to be felt in North Canterbury and it is the best documented and studied historical event since European settlement of the Canterbury region. It was felt from Taranaki to parts of Southland. It was accompanied by surface rupture on the Hope fault to the west of Hanmer Springs, and severe damage to slopes and buildings was reported from the Amuri District (McKay 1890; Cowan 1991). The effects of the earthquake indicate Modified Mercalli intensities of MM9 in the epicentral area with numerous landslides scarring fluvial and lacustrine Quaternary deposits, and large blocks of rock collapsing from bedrock outcrops. Liquefaction was evident near Glynn Wye, causing the formation or enlargement of large pits and sandblows. At many localities within the Amuri District there was moderate to severe damage to chimneys and household articles, while on the West Coast the strongest shaking was reported from the Otira Gorge, where new springs were observed (three hot and one cold), and a large fissure allegedly formed in Kelly's Creek. In the coastal towns of Hokitika and Greymouth, there were reports of chimney damage and breakage of goods, glass and crockery, but few other localities in Westland reported any damage (Cowan 1991). In Christchurch earthquake damage was reported in the northern and eastern suburbs generally with intensities of MM5 and MM6, but MM7 was experienced in some parts of the city. The Christchurch Cathedral spire partially collapsed during this earthquake.

Cheviot Earthquake: November 16, 1901:

This event is one of the strongest earthquakes to have occurred in the Canterbury region of the South Island since European settlement. Its magnitude has been estimated at around $6.5-7$ by Dibble et al. (1980) and $\mathrm{M}_{\mathrm{S}} 6.9 \pm 0.2$ by Dowrick and Smith (1990). Contemporary newspapers and scientific papers contain several reports of ejected sand and water in the epicentral region near Parnassus, and other incidents of lateral spreading due to liquefaction. Minor liquefaction occurred at Waikuku and Leithfield beaches. The most widely reported cases of liquefaction occurred in Kaiapoi, about $90 \mathrm{~km}$ south of the estimated epicentre. These reports and subsequent studies are discussed in detail by Berrill et al. (1994), who estimate that liquefaction occurred over an area of 2-3 town blocks at the eastern end of Sewell and Charles Streets. Buildings in Cheviot township were seriously damaged by earthquake shaking estimated at MM9. One death was reported. The earthquake was not attributed to a specific fault at the time, but the reported area of most intense shaking appears to coincide with the Kaiwara fault (Cowan et al. 1996). The event was felt from New Plymouth to Dunedin, but not apparently in Hawke's Bay, Wairarapa, or in Westland (Eiby 1968).

\section{Motunau Earthquake: December 25, 1922:}

Remembered as the Christmas Day Earthquake, and named the Motunau Earthquake by Elder et al. (1991), this event occurred just after $3 \mathrm{pm}$ when many people were enjoying their Christmas afternoon out of doors (Downes 1995). Felt from Taranaki to Dunedin, this earthquake produced shaking intensities of MM9 in the Waipara and Motunau areas of North Canterbury and is assigned an approximate local magnitude of $6.5-6.7$, and $M_{S} 6.4 \pm 0.1$ by Dowrick and Smith (1990). Intensities of at least MM7 were experienced in Rangiora, with liquefaction effects reported along the Pegasus Bay coast. Extensive damage was caused in North Canterbury, and from Cheviot to Rangiora large numbers of chimneys collapsed. Christchurch experienced intensities of MM6 with MM7 possibly occurring in some areas.

\section{Arthur's Pass Earthquake: March 09, 1929:}

This large earthquake was feit over the whole country except the Northland Peninsula. With a surface wave magnitude MS of $7.1 \pm 0.1$ (Dowrick and Smith 1990) this earthquake generated maximum intensities in excess of MM8 in the mountainous country northeast from Arthur's Pass (Cowan et al. 1996). The earthquake has been attributed to surface movement on the Kakapo fault by Yang (1991). Little attention was given to analyzing this event at the time it occurred as most damage occurred in a sparsely populated area and the earthquake was followed closely by the larger and more destructive Buller earthquake (MS 7.8). However, Speight (1933) studied the mountainous area to the north-east of Arthur's Pass some four years after the earthquake and noted the occurrence of numerous and large landslides in a narrow belt about forty kilometres long by four kilometres wide. The occurrence of slides dropped off rapidly outside this belt (Downes 1995). Intensities of MM6 was experienced in Christchurch (Dowrick pers. comm. 1997). Intensities of MM5 or more occurred over a large part of the Canterbury region.

\section{Buller Earthquake: June 16, 1929:}

This large earthquake $\left(M_{S}\right.$ 7.8, Dowrick and Smith 1990), is the second largest in New Zealand's recorded history. It occurred outside the Canterbury region but was responsible for intensities of MM5 or more over most of the region. Although no felt reports are available for the northwest of the region it can be inferred from the isoseismal map that intensities of MM7 were probably experienced. 
Lake Coleridge Earthquake: June 27, 1946:

This magnitude ML 6.2 earthquake was felt over most of the South Island, and was the subject of a special study by Eiby (1990). Intensities above MM7 were reported in the Lake Coleridge area, with minor structural damage to homesteads in the Upper Rakaia basin, and at the Lake Coleridge hydroelectric power station. There were also numerous landslides and changes to watercourses. It was preceded by two foreshocks and followed by numerous aftershocks, the largest of which had a magnitude of 5.8. These aftershocks persisted until the end of 1949 (Downes 1995)

Waiau Earthquake: May 23, 1948:

This little-studied earthquake, with a magnitude of ML 6.4, produced an intensity about MM8 in the epicentral region near the Waiau River. It was preceded by a foreshock of magnitude 5.5. At least four aftershocks above magnitude 5 are known (Eiby 1968). The largest (ML 6.2) of these occurred 15 minutes after the mainshock. The shock was felt over an area that included the northern half of the South Island and extended across Cook Strait to Wellington; but damage was confined to the settlements of Hanmer and Waiau and to the surrounding countryside.

Arthur's Pass Earthquake: June 18, 1994:

The central South Island was rocked by a sharp earthquake at $3: 25 \mathrm{pm}$ on June 18, 1994. The earthquake was centred near Arthur's Pass and had a local magnitude of 6.7. Shaking effects were reported from Invercargill to Taranaki, especially on the West Coast and in Canterbury. Major slips were triggered by this event along with slumping and cracking of the road between Arthur's Pass and Otira. Replies to a newspaper survey indicated intensities between MM6 and MM3 in Christchurch, and this matched instrumental recordings and other estimates (Toshinawa et al. 1997).

The main shock was followed on the $20^{\text {th }}$ June by a $M_{L} 6.0$ and on 21 June by a $M_{L} 6.0$ aftershock further south near the head of Lake Coleridge. A portable network of seismographs recorded over 5000 aftershocks in the first 6 days of the earthquake sequence. Another large earthquake was experienced in the area on May 29, 1995. The epicentre of this event $\left(M_{L} 6.0\right)$ was approximately $30 \mathrm{~km}$ north of the epicentre of the 1994 Arthur's Pass earthquake. It was widely felt from Nelson to South Canterbury and Westland. The Arthur's Pass area was most affected, with the road closed by large slips. There was minor damage at Arthur's Pass, Cass and Mount White Station. There were two smaller events $\left(\mathrm{M}_{\mathrm{L}}\right.$ 4.5 and $\mathrm{M}_{\mathrm{L}}$ 3.9) within minutes of that main shock.

Cass Earthquake: November 24, 1995 :

With a magnitude of $M_{L} 6.3$, this earthquake was larger than the event on 29 May 1995 (see above) but smaller than the June 1994 Arthur's Pass earthquake. It was felt throughout much of the South Island. Damage was reported at Arthur's Pass, Cass and Mount White Station (Gledhill et al. 2000). Minor damage was also reported from Westport and Christchurch. Peak ground accelerations in Christchurch were similar to the larger 1994 Arthur's Pass event. The largest aftershock $\left(M_{L} 5.2\right)$ occurred 26 hours later. 